\title{
Intracellular Nitrate of Marine Diatoms as a Driver of Anaerobic Nitrogen Cycling in Sinking Aggregates
}

\author{
Anja Kamp ${ }^{1 *}$, Peter Stief ${ }^{2}$, Laura A. Bristow ${ }^{2,3}$, Bo Thamdrup ${ }^{2}$ and Ronnie N. Glud ${ }^{2,4,5}$ \\ ${ }^{1}$ AlAS, Aarhus Institute of Advanced Studies, Aarhus University, Aarhus, Denmark, ${ }^{2}$ Department of Biology and Nordic \\ Center for Earth Evolution, University of Southern Denmark, Odense, Denmark, ${ }^{3}$ Department of Biogeochemistry, Max \\ Planck Institute for Marine Microbiology, Bremen, Germany, ${ }^{4}$ Department of Biogeochemistry and Earth Science, Scottish \\ Association for Marine Science, Oban, UK, ${ }^{5}$ Department of Bioscience, Arctic Research Centre, Aarhus University, Aarhus, \\ Denmark
}

OPEN ACCESS

Edited by:

Hongyue Dang,

Xiamen University, China

Reviewed by:

Phyllis Lam

University of Southampton, UK Daniel Conrad Ogilvie Thornton,

Texas A\&M University, USA

*Correspondence:

Anja Kamp

anjakamp@aias.au.dk

Specialty section:

This article was submitted to

Aquatic Microbiology,

a section of the journal

Frontiers in Microbiology

Received: 04 July 2016

Accepted: 06 October 2016

Published: 01 November 2016

Citation:

Kamp A, Stief P, Bristow LA,

Thamdrup B and Glud RN (2016)

Intracellular Nitrate of Marine Diatoms as a Driver of Anaerobic Nitrogen

Cycling in Sinking Aggregates.

Front. Microbiol. 7:1669.

doi: 10.3389/fmicb.2016.01669
Diatom-bacteria aggregates are key for the vertical transport of organic carbon in the ocean. Sinking aggregates also represent pelagic microniches with intensified microbial activity, oxygen depletion in the center, and anaerobic nitrogen cycling. Since some of the aggregate-forming diatom species store nitrate intracellularly, we explored the fate of intracellular nitrate and its availability for microbial metabolism within anoxic diatombacteria aggregates. The ubiquitous nitrate-storing diatom Skeletonema marinoi was studied as both axenic cultures and laboratory-produced diatom-bacteria aggregates. Stable ${ }^{15} \mathrm{~N}$ isotope incubations under dark and anoxic conditions revealed that axenic S. marinoi is able to reduce intracellular nitrate to ammonium that is immediately excreted by the cells. When exposed to a light:dark cycle and oxic conditions, S. marinoi stored nitrate intracellularly in concentrations $>60 \mathrm{mmol} \mathrm{L}^{-1}$ both as free-living cells and associated to aggregates. Intracellular nitrate concentrations exceeded extracellular concentrations by three orders of magnitude. Intracellular nitrate was used up within 2-3 days after shifting diatom-bacteria aggregates to dark and anoxic conditions. Thirtyone percent of the diatom-derived nitrate was converted to nitrogen gas, indicating that a substantial fraction of the intracellular nitrate pool of $S$. marinoi becomes available to the aggregate-associated bacterial community. Only $5 \%$ of the intracellular nitrate was reduced to ammonium, while 59\% was recovered as nitrite. Hence, aggregateassociated diatoms accumulate nitrate from the surrounding water and sustain complex nitrogen transformations, including loss of fixed nitrogen, in anoxic, pelagic microniches. Additionally, it may be expected that intracellular nitrate not converted before the aggregates have settled onto the seafloor could fuel benthic nitrogen transformations.

Keywords: nitrate respiration, denitrification, DNRA, nitrogen loss, low-oxygen environments, marine snow, stable isotopes

\section{INTRODUCTION}

The oceans teem with diatoms that can form huge phytoplankton blooms in surface layers (Leblanc et al., 2012; Simon et al., 2014). In the wake of these blooms, diatom-bacteria aggregates can form in masses and sink out of the photic zone toward the sea floor sustaining the benthic communities (Smetacek, 1985; Thornton, 2002). In polar regions, aggregates can also form at high abundance 
as sea ice melting leads to mass release of algae from brine channels and the underside of ice floes (Boetius et al., 2013; Fernández-Méndez et al., 2014; Glud et al., 2014; Boetius et al., 2015). Natural diatom-derived aggregates consist of a diverse assemblage of diatoms, the bacterial and archaeal community of surface waters (Thiele et al., 2015), viruses, other planktonic organisms, and detritus (Simon et al., 2002). Sinking organic aggregates, also named "marine snow," are extensively studied, often with a focus on the vertical transport of organic carbon to the seafloor by the "biological pump" (e.g., Riley, 1963; Silver et al., 1978; Shanks and Trent, 1979; Grossart et al., 1998; Simon et al., 2002; Turner, 2015). In contrast, organic nitrogen compounds are preferentially degraded during the sinking process, which increases the $\mathrm{C} / \mathrm{N}$ ratio of aggregates during their descent (Martin et al., 1987; Smith et al., 1992; Dang and Lovell, 2016). The vertical transport of intracellularly stored $\mathrm{NO}_{3}^{-}$within sinking diatom-bacteria aggregates (Stief et al., 2016) has so far not been documented in situ. To date, diatoms are the only known $\mathrm{NO}_{3}^{-}$-storing microorganisms in marine snow, e.g., the pelagic species Skeletonema marinoi and Thalassiosira weissflogii (Kamp et al., 2011, 2013; Stief et al., 2016). Both genera are very abundant in the ocean and can contribute significantly to spring blooms and subsequent aggregate formation (Bresnan et al., 2009; Degerlund and Eilertsen, 2010; Leblanc et al., 2012).

The pelagic, centric T. weissflogii as well as the benthic, pennate Amphora coffeaeformis are known to use intracellular $\mathrm{NO}_{3}^{-}$for dissimilatory nitrate reduction to ammonium (DNRA; $\mathrm{NO}_{3}^{-} \rightarrow \mathrm{NO}_{2}^{-} \rightarrow \mathrm{NH}_{4}^{+}$) after sudden shifts to dark and anoxic conditions (Kamp et al., 2011, 2013, 2015), which might also hold true for S. marinoi. DNRA is an anaerobic nitrate reduction pathway, which can be used to conserve energy in the absence of $\mathrm{O}_{2}$ (Kraft et al., 2011; Thamdrup, 2012). Instead of being used as terminal electron acceptor in anaerobic respiration, intracellular $\mathrm{NO}_{3}^{-}$may also serve as an electron sink for fermentation processes in diatoms exposed to anoxic conditions. This process would also produce $\mathrm{NH}_{4}^{+}$ that is eventually excreted by the cell, similar to "ammonia fermentation" in fungi (Zhou et al., 2002; Stief et al., 2014). Other energy-providing pathways of the anaerobic nitrogen cycle being of potential importance in diatom-bacteria aggregates include dissimilatory nitrate reduction to nitrite (DNRN; $\mathrm{NO}_{3}^{-} \rightarrow \mathrm{NO}_{2}^{-}$), denitrification $\left(\mathrm{NO}_{3}^{-} \rightarrow \mathrm{NO}_{2}^{-} \rightarrow \mathrm{NO} \rightarrow \mathrm{N}_{2} \mathrm{O} \rightarrow \mathrm{N}_{2}\right.$ ), incomplete denitrification $\left(\mathrm{NO}_{3}^{-} \rightarrow \mathrm{NO}_{2}^{-} \rightarrow \mathrm{NO} \rightarrow \mathrm{N}_{2} \mathrm{O}\right.$ ), and anammox $\left(\mathrm{NO}_{2}^{-}+\mathrm{NH}_{4}^{+} \rightarrow \mathrm{N}_{2}\right.$ ) (Stief et al., 2016).

Here, we focus on metabolic pathways of dissimilatory nitrate reduction performed by microorganisms exposed to anoxic environmental conditions. Diatom-bacteria aggregates, and "marine snow" in general, can be exposed to such conditions while sinking through oxygen-depleted water masses of oxygen minimum zones (OMZ's; Ploug and Bergkvist, 2015; Stief et al., 2016). However, even in oxic settings, enhanced microbial activity may facilitate the formation of central anoxia in sinking aggregates (Ploug et al., 1997; Klawonn et al., 2015; Stief et al., 2016). Indeed, DNRA has previously been observed in large aggregates exposed to $\mathrm{NO}_{3}^{-}$concentrations of 25$30 \mu \mathrm{mol} \mathrm{\textrm {L } ^ { - 1 }}$ in the surrounding seawater and to ambient $\mathrm{O}_{2}$ levels corresponding to $30-40 \%$ air saturation (Klawonn et al., 2015; Stief et al., 2016). Intracellular $\mathrm{NO}_{3}^{-}$stored by diatoms may, however, serve as a $\mathrm{NO}_{3}^{-}$source for dissimilatory nitrate reduction within diatom-bacteria aggregates, providing independence from external $\mathrm{NO}_{3}^{-}$supply and also allowing for respiratory organic carbon mineralization in the absence of $\mathrm{O}_{2}$ (Stief et al., 2016).

This study aims to reveal (a) whether the ubiquitous, aggregate-forming diatom $S$. marinoi is able to perform DNRA under dark and anoxic conditions, (b) whether and how fast the $\mathrm{NO}_{3}^{-}$stored intracellularly by aggregate-associated $S$. marinoi is used after shifting diatom-bacteria aggregates to dark and anoxic conditions, and (c) to what extent anoxic diatombacteria aggregates release $\mathrm{NH}_{4}^{+}$(from diatom-DNRA) into the surrounding water relative to other products of anaerobic nitrogen cycling inside the aggregates.

\section{MATERIALS AND METHODS}

\section{Strain and Cultivation}

An axenic strain of the marine pelagic, chain-forming, diatom S. marinoi (CCMP 1332) was obtained from the ProvasoliGuillard National Center for Marine Algae and Microbiota (NCMA; formerly CCMP). This strain was formerly referred to as $S$. costatum and has previously been studied for its intracellular $\mathrm{NO}_{3}^{-}$storage capacity (Kamp et al., 2011). The diatoms were cultured in F/2 medium plus silicate (Guillard and Ryther, 1962) prepared with filtered $(0.45 \mu \mathrm{m})$ and autoclaved Baltic Sea water (salinity adjusted to 30 ). The cultivation temperature was $14^{\circ} \mathrm{C}$, the light:dark cycle was 10:14 h, and the light intensity was $20 \mu \mathrm{mol}$ photons $\mathrm{m}^{-2} \mathrm{~s}^{-1}$. S. marinoi was frequently checked for possible contaminations with bacteria by careful phase-contrast microscopy and by plating out subsamples of the cultures on nutrient agar plates. Contamination of the cultures was not detected at any point during the present study.

\section{Dissimilatory Nitrate Reduction by Axenic Skeletonema marinoi}

Skeletonema marinoi was investigated for possible pathways of dissimilatory $\mathrm{NO}_{3}^{-}$reduction by ${ }^{15} \mathrm{~N}$ - stable isotope labeling of its intracellular $\mathrm{NO}_{3}^{-}$pool and following the time course of the intracellular ${ }^{15} \mathrm{NO}_{3}^{-}$concentration and the extracellular ${ }^{15} \mathrm{NH}_{4}^{+}$, ${ }^{15} \mathrm{NO}_{2}^{-}, \mathrm{N}_{2} \mathrm{O}$, and ${ }^{15} \mathrm{~N}_{2}$ concentrations in axenic S. marinoi cultures.

To prepare the $S$. marinoi cells for the experiment, their non-labeled intracellular $\mathrm{NO}_{3}^{-}$(i.e., intracellular ${ }^{14} \mathrm{NO}_{3}^{-}$) was replaced with ${ }^{15} \mathrm{~N}$-labeled intracellular $\mathrm{NO}_{3}^{-}$(i.e., intracellular ${ }^{15} \mathrm{NO}_{3}^{-}$). The cells were washed three times with sterile $\mathrm{NaCl}$ solution (salinity 30; $5 \mathrm{~min} ; 600 \mathrm{~g}$ ) to remove ${ }^{14} \mathrm{NO}_{3}^{-}$from the growth medium, flushed with $\mathrm{N}_{2}$ for $30 \mathrm{~min}$ to remove $\mathrm{O}_{2}$ (the $\mathrm{O}_{2}$ concentration was followed with optode spots; SensorSpot, Pyroscience, Germany), and incubated for $24 \mathrm{~h}$ in $\mathrm{NO}_{3}^{-}$-free $\mathrm{F} / 2$ medium plus silicate, to make the cells use up their intracellular ${ }^{14} \mathrm{NO}_{3}^{-}$. After this "starvation procedure," the cells were washed again and grown for $12 \mathrm{~h}$ in F/2 medium plus silicate, in which ${ }^{14} \mathrm{NO}_{3}^{-}$was replaced with ${ }^{15} \mathrm{NO}_{3}^{-}(50 \mu \mathrm{mol} \mathrm{L}-1 ; 98$ atom \%, 
Cambridge Isotope Laboratories), for subsequent accumulation of intracellular ${ }^{15} \mathrm{NO}_{3}^{-}$.

For the experimental incubation, the concentrations of $\mathrm{NH}_{4}^{+}$ (added to meet assimilation requirements) and sodium acetate (added as an electron donor) were adjusted to $100 \mu \mathrm{mol} \mathrm{L}^{-1}$ each in the growth medium and the S. marinoi culture was split in two.

(a) One half of the culture was transferred into a dark, gastight glass bottle, flushed with He for 30 min to introduce dark and anoxic conditions, thoroughly mixed, and distributed into $24(+3)$ replicate 6-mL gas-tight incubation vials (Labco, UK) wrapped in aluminum foil. At time intervals of $0.5,1,1.5,2$, $3,4,5$, and $6 \mathrm{~h}$, a He headspace of $3 \mathrm{~mL}$ was set in each of three incubation vials, and the diatoms in the remaining $3 \mathrm{~mL}$ were killed with $100 \mu \mathrm{L} \mathrm{ZnCl}_{2}$ (50\% w/v). The vials were stored upside-down at room temperature until measurement of ${ }^{15} \mathrm{~N}_{2}$ and $\mathrm{N}_{2} \mathrm{O}$ on a gas chromatography-isotopic ratio mass spectrometer (GC-IRMS; 184 Thermo Delta V Plus, Thermo Scientific; for details see Dalsgaard et al., 2012; Stief et al., 2016) and a gas chromatograph (GC 7890, Agilent Technologies), respectively. The cell suspensions collected during setting the headspace were filled into centrifugation tubes and centrifuged $\left(5 \mathrm{~min} ; 600 \mathrm{~g}\right.$ ). To calculate the intracellular $\mathrm{NO}_{3}^{-}$concentration, $25 \mu \mathrm{L}$ of the well-mixed pellet was diluted 1:10 in $\mathrm{NaCl}$ solution (salinity 30 ) plus $4 \%$ formaldehyde for diatom cell counting in a Fuchs-Rosenthal counting chamber. The remaining pellet and $100 \mu \mathrm{L}$ of the cell-free supernatant were separately frozen at $-20^{\circ} \mathrm{C}$ for (intracellular) $\mathrm{NO}_{3}^{-}$analyses with an $\mathrm{NO}_{\mathrm{x}}$ analyser (CLD 66s, EcoPhysics; for details see Kamp et al., 2011, 2013). The remaining cell-free supernatant was frozen at $-20^{\circ} \mathrm{C}$ for measurement of $\mathrm{NH}_{4}^{+},{ }^{15} \mathrm{NH}_{4}^{+}$, and ${ }^{15} \mathrm{NO}_{2}^{-}$concentrations (for details see Kamp et al., 2013; Stief et al., 2016). S. marinoi cells taken from three additional incubation vials were carefully investigated for bacterial contamination (see above) at the end of the experiment. No contamination was detected.

(b) The second half of the culture was kept under light and oxic conditions and sub-sampled at time intervals of $0,1,2,3,4$, 5 , and $6 \mathrm{~h}$ in triplicates each for the measurement of intracellular $\mathrm{NO}_{3}^{-}$and extracellular ${ }^{15} \mathrm{NH}_{4}^{+}$and total $\mathrm{NH}_{4}^{+}$concentrations.

Since the $\mathrm{NO}_{\mathrm{x}}$ analyzer does not discriminate between ${ }^{14} \mathrm{NO}_{3}^{-}$ and ${ }^{15} \mathrm{NO}_{3}^{-}$, and the intracellular ${ }^{14} \mathrm{NO}_{3}^{-}$pool of $S$. marinoi might not have been completely depleted prior to the incubation with ${ }^{15} \mathrm{NO}_{3}^{-}$(see "starvation procedure"), intracellular ${ }^{15} \mathrm{NO}_{3}^{-}$ was also measured with the cadmium/sulfamic acid assay in three samples taken at $\mathrm{t}_{0}$ (McIlvin and Altabet, 2005; Füssel et al., 2012). Together with the data obtained from the $\mathrm{NO}_{\mathrm{x}}$ analyzer (i.e., ${ }^{14+15} \mathrm{NO}_{3}^{-}$), the ${ }^{15} \mathrm{NO}_{3}^{-}$data were used to calculate the labeling fraction of the intracellular $\mathrm{NO}_{3}^{-}$pool at $t_{0}$, which amounted to $52.5 \pm 0.7 \%$. This initial labeling fraction was assumed to remain constant throughout the experimental incubation because $S$. marinoi does not replenish the intracellular $\mathrm{NO}_{3}^{-}$pool under anoxia (Supplementary Figure S1) and isotope fractionation during passive $\mathrm{NO}_{3}^{-}$leakage from diatom cells is very unlikely. The initial labeling fraction of the intracellular $\mathrm{NO}_{3}^{-}$pool was therefore used to convert the measured ${ }^{15} \mathrm{~N}$ concentrations to intracellular $\mathrm{NO}_{3}^{-}$-derived $\mathrm{N}$-concentrations (denoted as ${ }^{{ }^{\mathrm{IC}}} \mathrm{N}$ ) by dividing the ${ }^{15} \mathrm{~N}$-concentrations by 0.525 .

\section{Intracellular Nitrate Storage by Free-Living and Aggregate-Associated S. marinoi}

Free-living (axenic) S. marinoi cells as well as $S$. marinoi cells in diatom-bacteria aggregates were investigated for their $\mathrm{NO}_{3}^{-}$storage capacity under light and oxic conditions and its correlation to the extracellular $\mathrm{NO}_{3}^{-}$concentration, i.e., the $\mathrm{NO}_{3}^{-}$concentration in the surrounding seawater. In total, three batches of free-living S. marinoi cells and four batches of aggregate-associated $S$. marinoi cells were investigated at different extracellular $\mathrm{NO}_{3}^{-}$concentrations.

Free-living S. marinoi cells were cultivated in $\mathrm{F} / 2$ growth medium as described above, washed in nitrate-free $\mathrm{NaCl}$ solution (salinity 30 ), and then adjusted to $0,10,15,25,50(n=2), 60$, $100(n=2)$, and $500 \mu \mathrm{mol} \mathrm{L}^{-1} \mathrm{NO}_{3}^{-}$for $12-24 \mathrm{~h}$, after which the intracellular $\mathrm{NO}_{3}^{-}$content of the diatom cells was measured in up to three replicates as described above.

For the production of diatom-bacteria aggregates, $50 \mathrm{~mL}$ of a stationary-phase $S$. marinoi culture was mixed with $550 \mathrm{~mL}$ natural Baltic Sea water (salinity adjusted to 30 ) and filled into four glass bottles, and sealed without bubbles. These aggregateproduction bottles were mounted on a plankton wheel (diameter: $60 \mathrm{~cm}$ ) and continuously rotated to induce aggregate formation and to always keep the aggregates sinking (Stief et al., 2016). After aggregates had formed (2-3 days), the water in the four aggregate-production bottles was adjusted to $15,75,100$, or $350 \mu \mathrm{mol} \mathrm{L}-1 \mathrm{NO}_{3}^{-}$and the bottles were rotated on the plankton wheel for another $24 \mathrm{~h}$. The aggregates were then individually harvested from the aggregate-production bottles with a glass tube, sized along the three axes with a ruler, and transferred into a centrifugation tube together with water from the aggregateproduction bottle still adhering to the aggregate. After the aggregate had settled, $100 \mu \mathrm{L}$ of the supernatant was sampled and immediately frozen at $-20^{\circ} \mathrm{C}$ until $\mathrm{NO}_{3}^{-}$analysis (see above). The remaining water was carefully removed without destroying the aggregate. The centrifugation tubes were vigorously mixed to arrive at a homogenous suspension. A subsample of the aggregate suspension was taken for diatom cell counts (see above), and the remaining aggregate suspension was frozen in liquid nitrogen, exposed to three freeze-thaw cycles to extract intracellular $\mathrm{NO}_{3}^{-}$(Heisterkamp et al., 2012), and stored at $-20^{\circ} \mathrm{C}$ until $\mathrm{NO}_{3}^{-}$analysis (see above). The intracellular $\mathrm{NO}_{3}^{-}$concentration in the aggregate-associated diatom cells was calculated from the $\mathrm{NO}_{3}^{-}$concentrations in the supernatant and the extracted aggregate suspension, the diatom cell counts, and the aggregate volume (i.e., $3.5-6 \mathrm{~mm}^{3}$ for the four batches). The average cell volume of S. marinoi of $0.33 \mathrm{pL}$ was taken from Kamp et al. (2011).

\section{Consumption of Intracellular Nitrate in Diatom-Bacteria Aggregates}

Diatom-bacteria aggregates formed under oxic conditions in a light:dark cycle were investigated for the consumption of intracellular $\mathrm{NO}_{3}^{-}$after sudden shifts to dark and anoxic conditions, thereby mimicking conditions for an aggregate sinking through oxygen depleted waters. 
Aggregates were produced in two separate batches ('batch 1 ' and 'batch 2') as described above and under light and oxic conditions, thereby mimicking aggregate formation and intracellular $\mathrm{NO}_{3}^{-}$accumulation in the euphotic zone. Aggregates of 'batch 1' were pre-incubated in Baltic Sea water (salinity adjusted to $30,{ }^{14} \mathrm{NO}_{3}^{-}$adjusted to $75 \mu \mathrm{mol} \mathrm{L}-1$ ) for $24 \mathrm{~h}$. For the experimental incubation, seawater was flushed with $\mathrm{N}_{2}$ to remove $\mathrm{O}_{2}$ and filled into 6- $\mathrm{mL}$ incubation vials (Labco, UK). Aggregates of 'batch 2' were pre-incubated in $100 \mu \mathrm{mol} \mathrm{L}{ }^{-1}$ ${ }^{15} \mathrm{NO}_{3}^{-}$for $12 \mathrm{~h}$ (see next section). For the experimental incubation, seawater was flushed with $\mathrm{He}$ to remove $\mathrm{O}_{2}$ and to lower the $\mathrm{N}_{2}$ background and filled into 6-mL incubation vials. Ammonium and acetate were not added because organic matter mineralization inside the aggregates was expected to cover the possible demands for $\mathrm{N}$-assimilation and $\mathrm{C}$-dissimilation by diatoms and bacteria. Single aggregates were harvested from the pre-incubation bottles, sized as described above, and transferred into the incubation vials. Incubation vials were sealed, wrapped in aluminum foil, and mounted on the plankton wheel (except for the $t_{0}$ samples) to keep the aggregates sinking. At time intervals of $0,3,6,24$, and $48 \mathrm{~h}$, four incubation vials each were sacrificed and the samples were processed as described above for $\mathrm{NO}_{3}^{-}$analysis in aggregate-associated diatom cells and whole aggregates.

\section{Anaerobic Turnover of Intracellular Nitrate in Diatom-Bacteria Aggregates}

The conversion of intracellular vs. extracellular $\mathrm{NO}_{3}^{-}$to intermediates and products of dissimilatory $\mathrm{NO}_{3}^{-}$reduction inside sinking diatom-bacteria aggregates was investigated with a ${ }^{15} \mathrm{~N}$-stable isotope experiment.

Diatom-bacteria aggregates were produced as described above in natural Baltic Sea water (salinity adjusted to 30), but without adding ${ }^{14} \mathrm{NO}_{3}^{-}$above the natural background concentration of $15 \mu \mathrm{mol} \mathrm{NO}_{3}^{-} \mathrm{L}^{-1}$. Instead, $100 \mu \mathrm{mol} \mathrm{L}{ }^{-1}{ }^{15} \mathrm{NO}_{3}^{-}$was added to the aggregate-production bottle $24 \mathrm{~h}$ prior to the experimental incubation to allow diatoms to accumulate ${ }^{15} \mathrm{NO}_{3}^{-}$ intracellularly. Ellipsoidal aggregates of $6.1 \pm 2.1 \mathrm{~mm}^{3}$ formed within 3 days (aggregate 'batch 2'). Aggregates of this batch were also analyzed together with the aggregates of 'batch 1' with respect to storage and consumption of intracellular $\mathrm{NO}_{3}^{-}$(see previous section).

To remove all extracellular ${ }^{15} \mathrm{NO}_{3}^{-}$and to make intracellular ${ }^{15} \mathrm{NO}_{3}^{-}$the sole ${ }^{15} \mathrm{NO}_{3}^{-}$source in the experiment, aggregates were carefully washed in nitrate-free $\mathrm{NaCl}$ solution (salinity 30). After washing, the aggregates were sized with a ruler, and transferred into 6-mL incubation vials that were previously filled with anoxic Baltic Sea water (salinity adjusted to 30). Ammonium and acetate were not added for reasons given in the previous section. The incubation vials were sealed, wrapped in aluminum foil, and mounted on the rotating plankton wheel (except for the $t_{0}$ samples) to keep the aggregates sinking.

(a) At time intervals of $0,3,6,24,48$, and $72 \mathrm{~h}$ (diatomfree) water and intact aggregates were taken from three incubation vials each, frozen in liquid nitrogen to stop all metabolic activities and stored at $-20^{\circ} \mathrm{C}$ until analysis of intracellular ${ }^{15} \mathrm{NO}_{3}^{-}$and extracellular $\mathrm{NO}_{3}^{-}, \mathrm{NH}_{4}^{+}$, and $\mathrm{NO}_{2}^{-}$(see above).

(b) At parallel time intervals of 3, 6, 24, and $72 \mathrm{~h}$, a He headspace of $2.5 \mathrm{~mL}$ was set in three additional incubation vials each (note that this was done in additional incubation vials because setting the headspace tends to destroy the aggregates). The remaining sample volume of $3.5 \mathrm{~mL}$ was amended with $100 \mu \mathrm{L} \mathrm{ZnCl} 2(50 \% \mathrm{w} / \mathrm{v})$. The incubation vials were stored upside-down at room temperature until measurement of ${ }^{15} \mathrm{~N}_{2}$ and $\mathrm{N}_{2} \mathrm{O}$ concentrations (see above). The cell suspensions that were collected during setting the headspace were centrifuged ( $5 \mathrm{~min} ; 600 \mathrm{~g}$ ) and the supernatants were used for measuring extracellular ${ }^{15} \mathrm{NH}_{4}^{+}$and ${ }^{15} \mathrm{NO}_{2}^{-}$ concentrations.

The labeling fraction of the initial intracellular $\mathrm{NO}_{3}^{-}$pool of the diatoms was determined as described above and in this case was $37.2 \pm 9.3 \%(n=3)$. Assuming that this labeling fraction remains constant during the incubation (see above), the measured ${ }^{15} \mathrm{~N}$-concentrations of products (i.e., ${ }^{15} \mathrm{NO}_{2}^{-}$, ${ }^{15} \mathrm{NH}_{4}^{+}$, and ${ }^{15} \mathrm{~N}_{2}$ ) were converted to intracellular $\mathrm{NO}_{3}^{-}$derived $\mathrm{N}$-concentrations (i.e., ${ }^{\mathrm{IC}} \mathrm{NO}_{2}^{-},{ }^{\mathrm{IC}} \mathrm{NH}_{4}^{+}$, and ${ }^{\mathrm{IC}} \mathrm{N}_{2}$ ) by dividing the ${ }^{15} \mathrm{~N}$-concentrations by 0.372 . Extracellular, $\mathrm{NO}_{3}^{-}$-derived $\mathrm{N}$-concentrations of $\mathrm{NO}_{2}^{-}$and $\mathrm{NH}_{4}^{+}$(i.e., ${ }^{\mathrm{EC}} \mathrm{NO}_{2}^{-}$ and ${ }^{\mathrm{EC}} \mathrm{NH}_{4}^{+}$) were calculated from the changes in measured total concentrations (i.e., ${ }^{\mathrm{TOT}} \mathrm{NO}_{2}^{-}$and ${ }^{\mathrm{TOT}} \mathrm{NH}_{4}^{+}$) minus the calculated ${ }^{\mathrm{IC}} \mathrm{N}$-concentrations. ${ }^{\mathrm{TOT}} \mathrm{N}_{2}$-concentrations were derived by using the principles of random isotope pairing, i.e., ${ }^{\text {TOT }} \mathrm{N}_{2}=\left({ }^{29} \mathrm{~N}_{2}\right)^{2} /\left(4 \times{ }^{30} \mathrm{~N}_{2}\right)+{ }^{29} \mathrm{~N}_{2}+{ }^{30} \mathrm{~N}_{2}$ (Nielsen, 1992); and ${ }^{\mathrm{EC}} \mathrm{N}_{2}$-concentrations were calculated as described for ${ }^{\mathrm{EC}} \mathrm{NO}_{2}^{-}$and ${ }^{\mathrm{EC}} \mathrm{NH}_{4}^{+}$. Application of the isotope pairing technique is based on the assumptions that (a) denitrification is the only significant $\mathrm{N}_{2}$-producing process in diatom aggregates (Stief et al., 2016) and (b) ${ }^{15} \mathrm{NO}_{3}^{-}$and ${ }^{14} \mathrm{NO}_{3}^{-}$are uniformly mixed at the site where denitrification takes place. The latter may not hold in the aggregates, if ${ }^{15} \mathrm{NO}_{3}^{-}$is uniformly released in the anoxic center, while ${ }^{14} \mathrm{NO}_{3}^{-}$ decreases along a radial gradient into the center. This would result in an underestimation of ${ }^{\mathrm{TOT}} \mathrm{N}_{2}$ and thereby of ${ }^{\mathrm{EC}} \mathrm{N}_{2}$ concentrations.

\section{RESULTS}

\section{Dissimilatory Nitrate Reduction to Ammonium (DNRA) by Axenic Skeletonema marinoi}

The S. marinoi cells used in this experiment had stored intracellular $\mathrm{NO}_{3}^{-}$at a concentration of $13.9 \pm 0.4 \mathrm{mmol} \mathrm{L}^{-1}$ (mean $\pm \mathrm{SD}, n=3$ ). The time course of total intracellular $\mathrm{NO}_{3}^{-}$and intracellular $\mathrm{NO}_{3}^{-}$-derived ${ }^{\mathrm{IC}} \mathrm{NO}_{2}^{-},{ }^{\mathrm{IC}} \mathrm{NH}_{4}^{+}$, and ${ }^{\mathrm{IC}} \mathrm{N}_{2}$ concentrations in axenic $S$. marinoi cultures after the sudden shift to dark and anoxic conditions revealed that $\mathrm{NH}_{4}^{+}$was the only product arising from intracellular $\mathrm{NO}_{3}^{-}$consumption (Figure 1; Supplementary Table S1). A time-integrated mass balance calculation revealed that $90 \%$ of the intracellular $\mathrm{NO}_{3}^{-}$ 


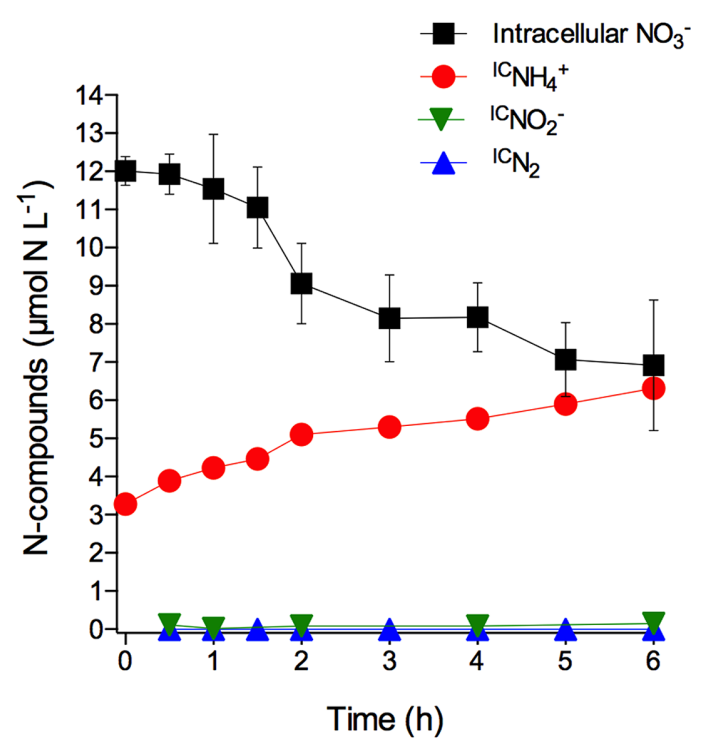

FIGURE 1 | Dissimilatory nitrate reduction to ammonium (DNRA) by axenic Skeletonema marinoi. Time course of intracellular $\mathrm{NO}_{3}^{-}$(expressed in $\mu \mathrm{mol} \mathrm{N} \mathrm{L}{ }^{-1}$ of growth medium; the initial $\mathrm{NO}_{3}^{-}$concentration per cell was $13.9 \pm 0.4 \mathrm{mmol} \mathrm{L}{ }^{-1}$ ) and extracellular, but intracellular $\mathrm{NO}_{3}^{-}$-derived ${ }^{\mathrm{IC}} \mathrm{NH}_{4}^{+}$, ${ }^{\mathrm{IC}} \mathrm{NO}_{2}^{-}$, and ${ }^{\mathrm{IC}} \mathrm{N}_{2}$ concentrations in axenic $S$. marinoi cultures in response to dark and anoxic conditions that were initiated directly after $t_{0}$. Some of the error bars, which indicate standard deviation $(n=3)$, are smaller than the symbols.

was converted to ${ }^{\mathrm{IC}} \mathrm{NH}_{4}^{+}$during the incubation period of $6 \mathrm{~h}$. The initial ${ }^{\mathrm{IC}} \mathrm{NH}_{4}^{+}$concentration of $3.3 \mu \mathrm{mol} \mathrm{L} \mathrm{L}^{-1}$ is likely due to the production and release of ${ }^{\mathrm{IC}} \mathrm{NH}_{4}^{+}$during the time period needed to shift the diatom culture to dark and anoxic conditions. Taken together, the data shows that S. marinoi is able to perform DNRA under dark and anoxic conditions (but see restrictive interpretation in the Introduction). Furthermore, the temporal coincidence of intracellular $\mathrm{NO}_{3}^{-}$ consumption and ${ }^{\mathrm{IC}} \mathrm{NH}_{4}^{+}$production rules out the possibility of $\mathrm{NO}_{3}^{-}$assimilation, followed by protein degradation and subsequent $\mathrm{NH}_{4}^{+}$release. Since ${ }^{\mathrm{IC}} \mathrm{NO}_{2}^{-}$and ${ }^{\mathrm{IC}} \mathrm{N}_{2}$ production were not observed, $\mathrm{S}$. marinoi seems incapable of dissimilatory $\mathrm{NO}_{3}^{-}$reduction to $\mathrm{NO}_{2}^{-}$(DNRN) as a stand-alone process, denitrification, and anammox.

Under light/oxic conditions, the intracellular $\mathrm{NO}_{3}^{-}$ concentration decreased only slightly during the $6 \mathrm{~h}$ incubation $\left(-0.06 \pm 0.03 \mathrm{fmol} \mathrm{NO}_{3}^{-}\right.$cell ${ }^{-1} \mathrm{~h}^{-1}$ under light/oxic conditions vs. $-0.36 \pm 0.04 \mathrm{fmol} \mathrm{NO}_{3}^{-}$cell $^{-1} \mathrm{~h}^{-1}$ under dark/anoxic conditions; linear regression), probably due to assimilation and/or leakage of intracellular $\mathrm{NO}_{3}^{-}$. In contrast to anoxic conditions, $\mathrm{NH}_{4}^{+}$was not released in measurable quantities by $S$. marinoi in oxic conditions (data not shown). Non-

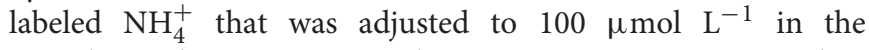
growth medium prior to the experiment, was not taken up under anoxic conditions, but decreased under oxic conditions from $96 \pm 14$ to $43 \pm 4 \mu \mathrm{mol} \mathrm{NH} \mathrm{NH}^{+} \mathrm{L}^{-1}$ during the $6 \mathrm{~h}$ incubation, probably due to assimilation (data not shown).

\section{Intracellular Nitrate Storage by Free-Living and Aggregate-Associated S. marinoi}

Intracellular $\mathrm{NO}_{3}^{-}$concentrations in free-living S. marinoi cells as well as in $S$. marinoi cells in diatom-bacteria aggregates grown or kept under light/oxic conditions were not correlated to extracellular $\mathrm{NO}_{3}^{-}$concentrations, with the exception that no intracellular $\mathrm{NO}_{3}^{-}$was detected at an extracellular $\mathrm{NO}_{3}^{-}$concentration of $0 \mu \mathrm{mol} \mathrm{\textrm {L } ^ { - 1 }}$ (Figure 2). Additionally, the $\mathrm{NO}_{3}^{-}$storage capacity of freeliving and aggregate-associated $S$. marinoi cells was in the same concentration range (i.e., 6-62 and $18-51 \mathrm{mmol} \mathrm{L}^{-1}$, respectively).

\section{Consumption of Intracellular Nitrate in Diatom-Bacteria Aggregates}

The diatom-bacteria aggregates had accumulated $\mathrm{NO}_{3}^{-}$at concentrations that were 2-3 orders of magnitude higher than extracellular $\mathrm{NO}_{3}^{-}$concentrations. In aggregate 'batch 1,' intracellular $\mathrm{NO}_{3}^{-}$was initially stored at concentrations of $51.0 \pm 6.6 \mathrm{mmol} \mathrm{\textrm {L } ^ { - 1 }}$ based on diatom cell volume, and $4.2 \pm 1.1 \mathrm{mmol} \mathrm{L}^{-1}$ based on aggregate volume [mean $\pm \mathrm{SD}$ of 12 samples taken at 0-6 h (see below); Figures 3A,B]; in aggregate 'batch 2', initial intracellular $\mathrm{NO}_{3}^{-}$was $18.0 \pm 3.3 \mathrm{mmol} \mathrm{L}-1$ per cell, and $1.4 \pm 0.3 \mathrm{mmol} \mathrm{L}^{-1}$ per aggregate (mean $\pm \mathrm{SD}$ of nine samples taken at $0-6 \mathrm{~h}$; Figures 3A,B). Assuming that the extracellular $\mathrm{NO}_{3}^{-}$concentration in the porewater of

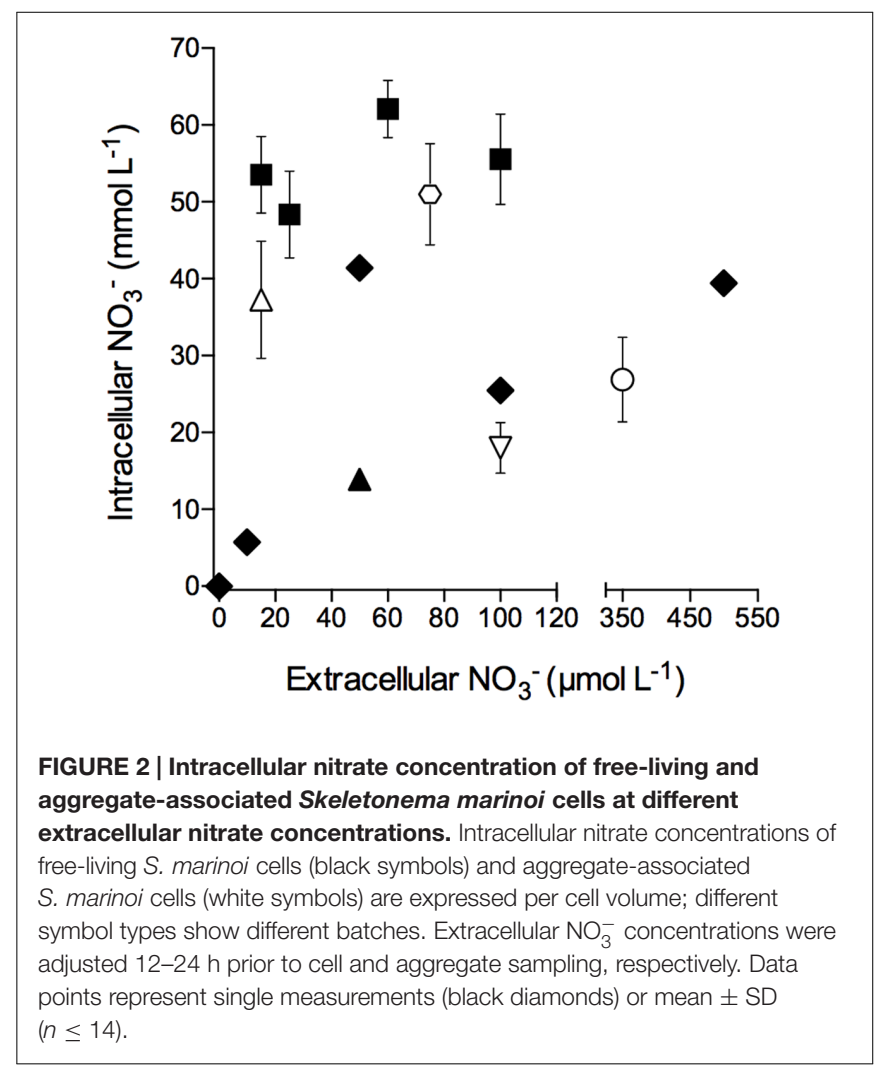


A

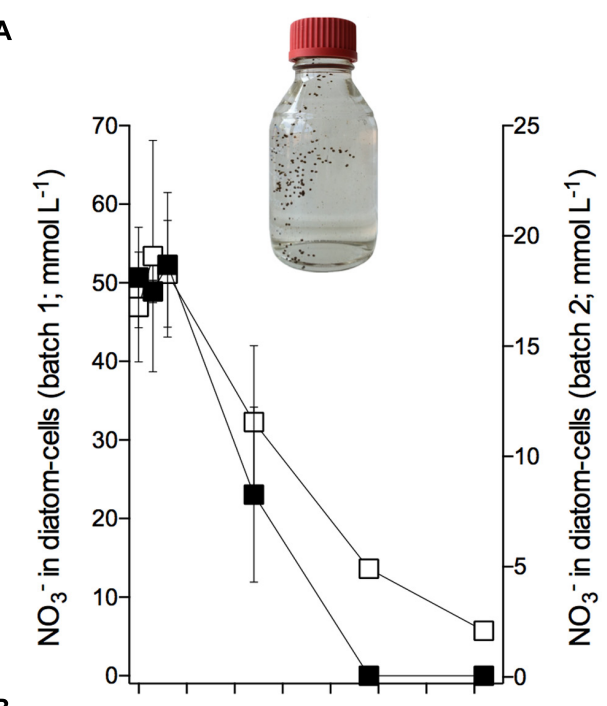

B

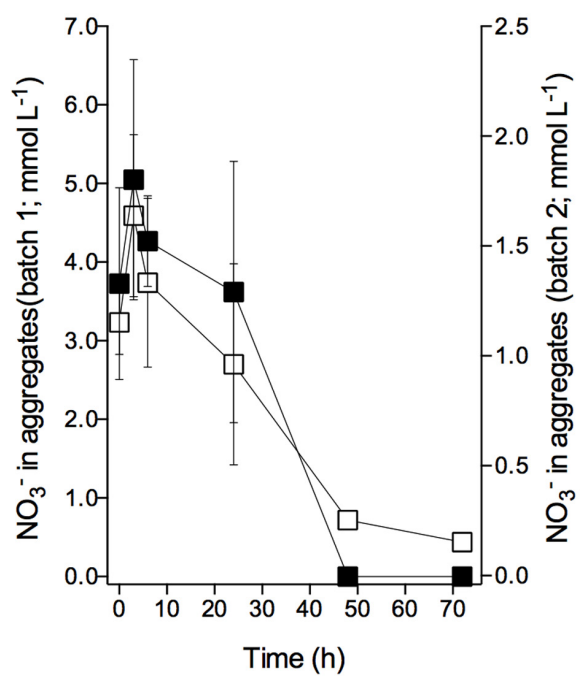

FIGURE 3 | Consumption of intracellular nitrate by Skeletonema marinoi in diatom-bacteria aggregates. Time course of intracellular $\mathrm{NO}_{3}^{-}$ concentrations in diatom-bacteria aggregates expressed per $(\mathbf{A})$ diatom cell volume and (B) aggregate volume. (A,B) Left y-axes scale cells and aggregates of 'batch 1' (black squares), and right y-axes scale cells and aggregates of 'batch 2' (white squares). Dark and anoxic conditions were initiated directly after $t_{0}$. Values are mean $\pm \operatorname{SD}(n=4$ for 'batch 1 ,' $n=3$ for 'batch 2'). Picture shows an example of an aggregate-production bottle with sinking, brownish, ellipsoidal diatom-bacteria aggregates. Aggregate volumes were $4.1 \pm 1.9$ for 'batch 1' and $6.1 \pm 2.1 \mathrm{~mm}^{3}$ for 'batch 2' (mean $\pm \mathrm{SD}$ ).

the aggregate was similar to the adjusted extracellular $\mathrm{NO}_{3}^{-}$ concentration (i.e., 75 and $100 \mu \mathrm{mol} \mathrm{L}^{-1}$ in 'batch 1 ' and 'batch 2,' respectively), the standing stock of $\mathrm{NO}_{3}^{-}$inside diatom-bacteria aggregates was largely (i.e., $\geq 98 \%$ ) contained in diatom cells.

Within the first $6 \mathrm{~h}$ of incubation under dark and anoxic conditions, the intracellular $\mathrm{NO}_{3}^{-}$concentration of the diatombacteria aggregates did not change significantly over time (Figures 3A,B; Supplementary Table S2). The scatter in the data may, however, have masked a potential decrease in intracellular $\mathrm{NO}_{3}^{-}$concentration during this short time period.
After $6 \mathrm{~h}$, however, intracellular $\mathrm{NO}_{3}^{-}$was rapidly consumed in aggregate 'batch $1^{\prime}$ at a rate of $-0.37 \pm 0.03 \mathrm{fmol} \mathrm{NO}_{3}^{-}$ diatom-cell ${ }^{-1} \mathrm{~h}^{-1}$ or $-361.78 \pm 95.12 \mathrm{nmol} \mathrm{NO}_{3}^{-}$aggregate $^{-1}$ $\mathrm{h}^{-1}$. The intracellular pool was completely consumed after $48 \mathrm{~h}$. In aggregate 'batch 2', intracellular $\mathrm{NO}_{3}^{-}$consumption within the first $48 \mathrm{~h}$ was $-0.09 \pm 0.01$ fmol $\mathrm{NO}_{3}^{-}$diatomcell $^{-1} \mathrm{~h}^{-1}$ or $-145.00 \pm 35.79 \mathrm{nmol} \mathrm{NO}_{3}^{-}$aggregate $^{-1} \mathrm{~h}^{-1}$, but continued at a lower rate after $48 \mathrm{~h}$ and $\mathrm{NO}_{3}^{-}$was not completely used up after $72 \mathrm{~h}$ (Figures 3A,B; Supplementary Table S2). Thus, irrespective of the different conditions that the aggregates experienced during the pre-incubation (regarding extracellular $\mathrm{NO}_{3}^{-}$concentration and exposure time), the aggregates displayed the same temporal pattern of intracellular $\mathrm{NO}_{3}^{-}$consumption during incubation under dark and anoxic conditions.

\section{Anaerobic Turnover of Intracellular Nitrate in Diatom-Bacteria Aggregates}

Only after $6 \mathrm{~h}$ of incubation, significant concentration changes of intra- and extracellular $\mathrm{NO}_{3}^{-}$as well as of extracellular $\mathrm{NO}_{2}^{-}$, $\mathrm{N}_{2}$, and $\mathrm{NH}_{4}^{+}$were observed (Figures 4A,B; Supplementary Table S3). What may look like an increase in intracellular $\mathrm{NO}_{3}^{-}$ concentration within the first $6 \mathrm{~h}$ of incubation is actually not statistically significant (Figure 4A; Supplementary Table S3). However, scatter in the data may have masked a potential net turnover of intra- and extracellular $\mathrm{NO}_{3}^{-}$during this initial time period. In contrast to the exclusive production of $\mathrm{NH}_{4}^{+}$ in the axenic cultures, the consumption of intracellular $\mathrm{NO}_{3}^{-}$ during anoxic incubation of aggregates was accompanied by the production and release of ${ }^{\mathrm{IC}} \mathrm{NO}_{2}^{-},{ }^{\mathrm{IC}} \mathrm{N}_{2}$, and ${ }^{\mathrm{IC}} \mathrm{NH}_{4}^{+}$from the aggregates (Figure 4A). Extracellular $\mathrm{NO}_{3}^{-}$present in the seawater showed a similar temporal pattern of consumption and was likewise accompanied by the production and release of ${ }^{\mathrm{EC}} \mathrm{NO}_{2}^{-},{ }^{\mathrm{EC}} \mathrm{N}_{2}$, and ${ }^{\mathrm{EC}} \mathrm{NH}_{4}^{+}$from the aggregates, though at higher concentrations than observed for the intracellular $\mathrm{NO}_{3}^{-}$derived products (Figure 4B). This likely reflects the higher supply rate of extracellular $\mathrm{NO}_{3}^{-}$diffusing into the aggregate from the surrounding water compared to the presumably slow release of intracellular $\mathrm{NO}_{3}^{-}$from the diatom cells into the aggregate. Both ${ }^{\mathrm{IC}} \mathrm{NO}_{2}^{-}$and ${ }^{\mathrm{EC}} \mathrm{NO}_{2}^{-}$concentrations peaked after $48 \mathrm{~h}$ incubation and decreased thereafter. In contrast, ${ }^{\mathrm{IC}} \mathrm{NH}_{4}^{+}$and ${ }^{\mathrm{EC}} \mathrm{NH}_{4}^{+}$concentrations increased significantly only after 48 h. ${ }^{I C} \mathrm{~N}_{2}$ and ${ }^{E C} \mathrm{~N}_{2}$ were produced from the onset and throughout the entire incubation period. A time-integrated budget shows that in total $95 \%$ of the intracellular $\mathrm{NO}_{3}^{-}$was consumed within the first $48 \mathrm{~h}$ and retrieved as ${ }^{\mathrm{IC}} \mathrm{NO}_{2}^{-}$(59\%), ${ }^{\mathrm{IC}} \mathrm{N}_{2}$ (31\%), and ${ }^{\mathrm{IC}} \mathrm{NH}_{4}^{+}$(5\%). In contrast, only $49 \%$ of the extracellular $\mathrm{NO}_{3}^{-}$that was consumed within the first $48 \mathrm{~h}$ was retrieved as ${ }^{\mathrm{EC}} \mathrm{NO}_{2}^{-}(35 \%),{ }^{\mathrm{EC}} \mathrm{N}_{2}$ (14\%), and ${ }^{\mathrm{EC}} \mathrm{NH}_{4}^{+}$ $(<1 \%)$.

Notably, in the diatom-bacteria aggregates, the production of ${ }^{\mathrm{IC}} \mathrm{NH}_{4}^{+}$did not coincide with the consumption of intracellular $\mathrm{NO}_{3}^{-}$, as was the case in the experiments with axenic S. marinoi (Figure 1; Supplementary Table S1), but occurred with a delay of ca. 2 days (Figures 4A,B; Supplementary Table S3). Additionally, ${ }^{\mathrm{IC}} \mathrm{NO}_{2}^{-}$and ${ }^{\mathrm{IC}} \mathrm{N}_{2}$ were important 

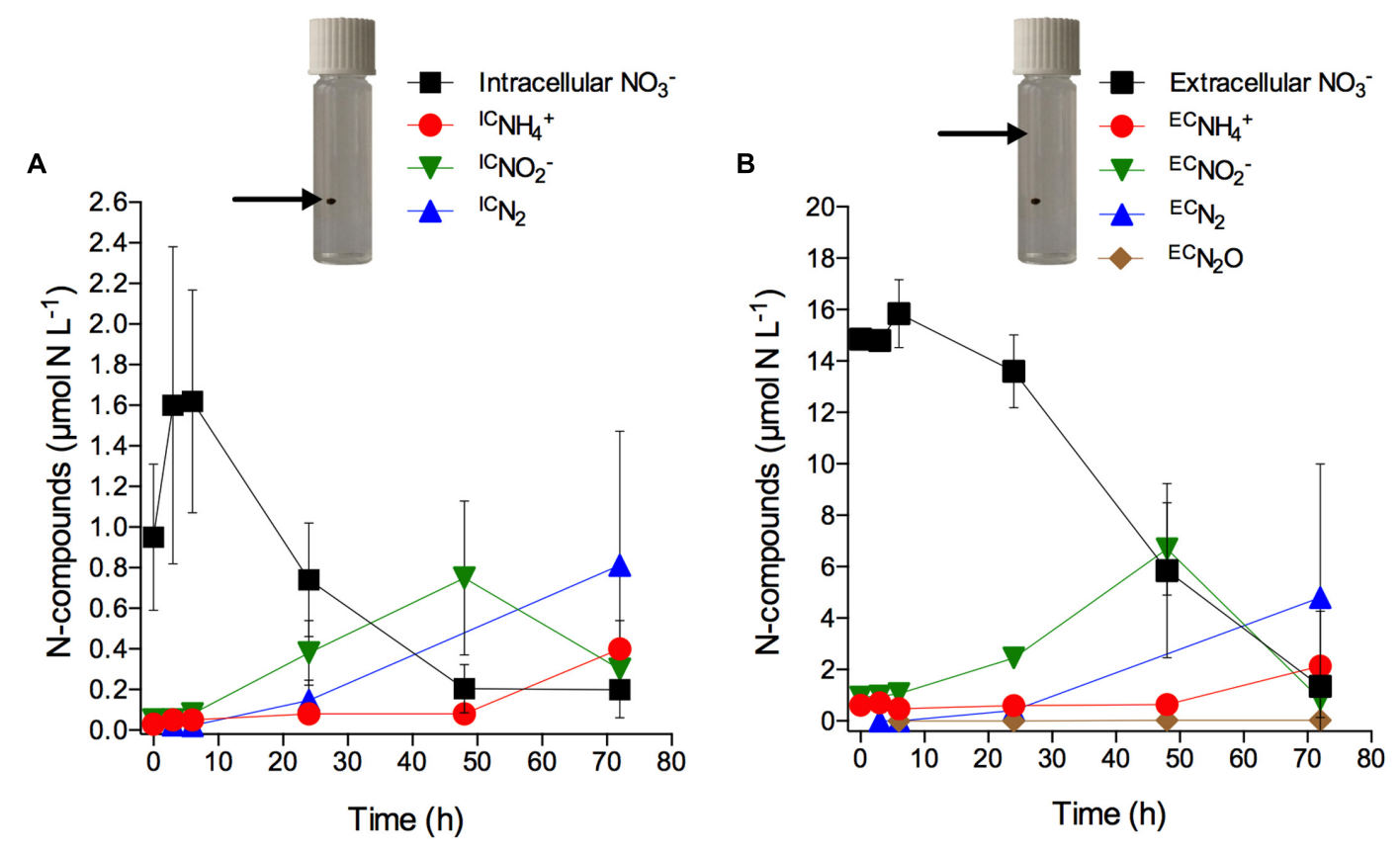

FIGURE 4 | Anaerobic turnover of intracellular nitrate in diatom-bacteria aggregates. Concentration time series of $(\mathbf{A})$ intracellular $\mathrm{NO}_{3}^{-}$(expressed in $\mu$ mol $\mathrm{N} \mathrm{L}^{-1}$ of incubation water; initial $\mathrm{NO}_{3}^{-}$concentration per cell was $18.0 \pm 3.3 \mathrm{mmol} \mathrm{L}^{-1}$ ) and intracellular $\mathrm{NO}_{3}^{-}-{ }_{\text {derived }}{ }^{1 C} \mathrm{NH}_{4}^{+}$, ${ }^{I C} \mathrm{NO}_{2}^{-}$, and ${ }^{I C} \mathrm{~N}_{2}$, and $(\mathbf{B})$ extracellular $\mathrm{NO}_{3}^{-}$and extracellular $\mathrm{NO}_{3}^{-}$-derived ${ }^{\mathrm{EC}} \mathrm{NH}_{4}^{+},{ }^{\mathrm{EC}} \mathrm{NO}_{2}^{-},{ }^{\mathrm{EC}} \mathrm{N}_{2}$, and ${ }^{\mathrm{EC}} \mathrm{N}_{2} \mathrm{O}$ (see Materials and Methods for the calculation of ${ }^{\mathrm{IC}} \mathrm{N}$ - and ${ }^{\mathrm{EC}} \mathrm{N}$-concentrations). Dark and anoxic conditions were initiated directly after $t_{0}$. Values are means $\pm \mathrm{SD}(n=3)$. Note different scales. Pictures show incubation vials with diatom-bacteria aggregates; arrows indicate the respective source of $\mathrm{NO}_{3}^{-}$that drives anaerobic nitrogen cycling (i.e., intracellular $\mathrm{NO}_{3}^{-}$inside the aggregate vs. extracellular $\mathrm{NO}_{3}^{-}$in the surrounding water).

products of intracellular $\mathrm{NO}_{3}^{-}$consumption in the diatombacteria aggregates, but not in the axenic $S$. marinoi cultures. Thus, intracellular $\mathrm{NO}_{3}^{-}$must have been made accessible to other microorganisms inside the diatom-bacteria aggregates contributing to complex anaerobic nitrogen cycling during the dark and anoxic incubation.

\section{DISCUSSION}

\section{Dissimilatory Nitrate Reduction to Ammonium (DNRA) by Axenic Skeletonema marinoi}

The aggregate-forming diatom S. marinoi uses intracellularly stored $\mathrm{NO}_{3}^{-}$for the dissimilatory $\mathrm{NO}_{3}^{-}$reduction pathway DNRA under dark and anoxic conditions and is thus the third diatom species that has been positively tested for DNRA in axenic cultures. Previously, DNRA has been found in the benthic diatom A. coffeaeformis and the pelagic, aggregate-forming T. weissflogii (Kamp et al., 2011, 2013, 2015). Thus, DNRA might be a widely distributed anaerobic metabolic pathway used by diatoms that are (temporarily) exposed to anoxic conditions in the dark, where neither photosynthesis, nor aerobic respiration is possible.

Dissimilatory nitrate reduction to ammonium activity by S. marinoi is fueled by intracellular $\mathrm{NO}_{3}^{-}$that has been accumulated under light and oxic conditions, where it is used for assimilation (e.g., Eppley and Rogers, 1970; Clark et al., 2002; Brown et al., 2009; Bender et al., 2012; Glibert et al., 2016) or stored for later use in assimilatory or dissimilatory pathways. Nitrate uptake under anoxic conditions has, to our knowledge, not been documented and was also not observed in this study (Supplementary Figure S1). The maximum intracellular $\mathrm{NO}_{3}^{-}$concentration found in S. marinoi was $62.0 \pm 0.7 \mathrm{mmol} \mathrm{L}^{-1}$ and was measured in cells that had been exposed to an extracellular $\mathrm{NO}_{3}^{-}$concentration of $58 \mu \mathrm{mol} \mathrm{L}{ }^{-1}$. Intracellular and extracellular $\mathrm{NO}_{3}^{-}$concentrations were apparently not directly correlated for $S$. marinoi, at least not in the targeted concentration range (Figure 2). The $\mathrm{NO}_{3}^{-}$ uptake and/or storage capacity of $S$. marinoi might depend on factors other than the extracellular $\mathrm{NO}_{3}$ concentration, such as temperature (Eppley and Coatsworth, 1968; Collos et al., 1992; Lomas and Glibert, 1999a; Tantanasarit et al., 2013), the physiological state of the cells, or the extracellular $\mathrm{NH}_{4}^{+}$concentration (Lomas and Glibert, 1999b; Glibert et al., 2016).

Interestingly, the depletion of the intracellular $\mathrm{NO}_{3}^{-}$pool of $S$. marinoi under anoxic conditions may take more than 2 days (Figure 3), whereas A. coffeaeformis and T. weissflogii completely use up their intracellular $\mathrm{NO}_{3}^{-}$pools within less than $24 \mathrm{~h}$ after exposure to darkness and anoxia (Kamp et al., 2011, 2013). This was supported by the observation that $S$. marinoi cells that were first subjected to the "starvation procedure" and then exposed to 
${ }^{15} \mathrm{NO}_{3}^{-}$had an isotopically mixed intracellular $\mathrm{NO}_{3}^{-}$pool (i.e., ${ }^{14} \mathrm{NO}_{3}^{-}$and ${ }^{15} \mathrm{NO}_{3}^{-}$). The intracellular $\mathrm{NO}_{3}^{-}$consumption rate immediately after exposure of $S$. marinoi to darkness and anoxia was 3-25 times lower for S. marinoi $\left(0.36 \mathrm{fmol} \mathrm{NO}_{3}^{-} \mathrm{cell}^{-1} \mathrm{~h}^{-1}\right.$, Figure 1) than for T. weissflogii (1.15-7.47 $\mathrm{fmol} \mathrm{NO}_{3}^{-}$cell ${ }^{-1} \mathrm{~h}^{-1}$; Kamp et al., 2013), and A. coffeaeformis (9.1 fmol $\mathrm{NO}_{3}^{-}$ cell $^{-1} \mathrm{~h}^{-1}$; Kamp et al., 2011). Likewise, the absolute amount of $\mathrm{NO}_{3}^{-}$stored per cell was 7-35 times lower for S. marinoi (1.9-20.4 fmol $\mathrm{NO}_{3}^{-}$cell ${ }^{-1}$, Figure 2) than for $T$. weissflogii (113 fmol $\mathrm{NO}_{3}^{-}$cell $^{-1}$; Kamp et al., 2011) and A. coffeaeformis (129 fmol $\mathrm{NO}_{3}^{-}$cell $^{-1}$; Kamp et al., 2011). Thus, despite the roughly similar ratio between pool size and consumption rate of intracellular $\mathrm{NO}_{3}^{-}$among the three investigated diatom species, the intracellular $\mathrm{NO}_{3}^{-}$pool in $S$. marinoi can sustain DNRA for a longer period than $T$. weissflogii and A. coffeaeformis. The intracellular $\mathrm{NO}_{3}^{-}$consumption rate of $S$. marinoi depends, however, on the initial intracellular $\mathrm{NO}_{3}^{-}$concentration. The more $\mathrm{NO}_{3}^{-}$that is stored, the higher the consumption rate because $\mathrm{NO}_{3}^{-}$is largely consumed within a certain time frame (approximately 1-2 days for $S$. marinoi). The consumption rate might actually be overestimated, if $\mathrm{NO}_{3}^{-}$leaks out of the cell, e.g., if the high concentration gradient between intra- and extracellular $\mathrm{NO}_{3}^{-}$is not maintainable in darkness and anoxia. Nitrate leakage may also partly explain that only $90 \%$ of the intracellular $\mathrm{NO}_{3}^{-}$lost during the 6 -h incubation was retrieved as $\mathrm{NH}_{4}^{+}$.

Intracellular $\mathrm{NO}_{3}^{-}$consumption rates of foraminifera that are capable of denitrification in the absence of $\mathrm{O}_{2}$ are $\sim 100$ times higher (1.7-83 pmol cell ${ }^{-1} \mathrm{~h}^{-1}$; Risgaard-Petersen et al., 2006; Høgslund et al., 2008; Piña-Ochoa et al., 2010a,b; Bernhard et al., 2012) than those of diatoms capable of DNRA, while the absolute amounts of $\mathrm{NO}_{3}^{-}$stored per cell are up to $\sim 10^{5}$ times higher (18 nmol NO $\mathrm{n}_{3}^{-}$cell $^{-1}$; Risgaard-Petersen et al., 2006). Therefore, it is not surprising that the intracellular $\mathrm{NO}_{3}^{-}$stores of foraminifera were estimated to sustain denitrification and thus survival under anoxic conditions for much longer periods (i.e., over a month; Risgaard-Petersen et al., 2006; Glud et al., 2009). In contrast, it was hypothesized that diatoms use intracellular $\mathrm{NO}_{3}^{-}$-fueled DNRA for entering a resting stage rather than for long-term survival with an active anaerobic metabolism (Kamp et al., 2011). Diatoms are generally known to survive dark and anoxic conditions in marine sediments for several years or even decades as resting spores (Lewis et al., 1999; McQuoid et al., 2002; Jewson et al., 2006; Härnström et al., 2011). Given the large phylogenetic diversity of diatoms of up to 100.000 species (Leblanc et al., 2012) and the pronounced genetic variation in diatoms (Armbrust et al., 2004; Bowler et al., 2008; Prihoda et al., 2012), it seems likely that diatoms have also evolved mechanisms other than DNRA to remain metabolically active during darkness and anoxia, or hitherto unrecognized pathways of anaerobic metabolism.

\section{Anaerobic Turnover of Intracellular Nitrate in Diatom-Bacteria Aggregates}

Diatom-bacteria aggregates produced from axenic S. marinoi and the natural bacterial community of coastal seawater contained high amounts of intracellular $\mathrm{NO}_{3}^{-}$at the end of the aggregate-production phase in a diel light:dark cycle. It has previously been shown for $S$. marinoi aggregates that the total intracellular $\mathrm{NO}_{3}^{-}$content increases with aggregate volume, whereas the aggregate-volume-specific intracellular $\mathrm{NO}_{3}^{-}$content decreases with aggregate volume (Stief et al., 2016). The first observation is consistent with this study, with a larger number of diatom cells in larger aggregates that can store more intracellular $\mathrm{NO}_{3}^{-}$in absolute amounts (Supplementary Figure S2). Aggregates larger than $2 \mu \mathrm{L}$ in volume had a lower diatom cell density than the smaller aggregates, which is consistent with the previously observed lower volume-specific intracellular $\mathrm{NO}_{3}^{-}$content of larger aggregates. This may indicate that the diatom cells in the outer shell of the aggregates mainly take up $\mathrm{NO}_{3}^{-}$from the surrounding water because $\mathrm{NO}_{3}^{-}$transport into the center of the aggregates is diffusion-limited. However, direct comparison of free-living and aggregate-associated S. marinoi cells did not reveal any difference in $\mathrm{NO}_{3}^{-}$storage capacity (6-63 and 18-51 mmol L $\mathrm{m}^{-1}$, respectively, Figure 2), rendering a strong influence of diffusion limitation on $\mathrm{NO}_{3}^{-}$transport unlikely. Additionally, the high cell densities in the aggregates and the possible competition for $\mathrm{NO}_{3}^{-}$do not seem to lower the ability to accumulate $\mathrm{NO}_{3}^{-}$in aggregate-associated S. marinoi cells.

When diatom-bacteria aggregates were exposed to dark and anoxic conditions, their intracellular $\mathrm{NO}_{3}^{-}$content was used up within 2-3 days at similar cellular rates as observed in the axenic, free-living $S$. marinoi. Based on the cell-specific intracellular $\mathrm{NO}_{3}^{-}$consumption rate of axenic $S$. marinoi ( $0.36 \mathrm{fmol} \mathrm{NO}_{3}^{-}$cell $^{-1} \mathrm{~h}^{-1}$ ) and the total number of $S$. marinoi cells in aggregates $\left(0.5-2.1 \times 10^{6}\right.$ cells aggregate $\left.^{-1}\right)$, an intracellular $\mathrm{NO}_{3}^{-}$consumption rate of $0.18-0.76 \mathrm{nmol} \mathrm{NO}-$ aggregate $^{-1} \mathrm{~h}^{-1}$ can be projected. This agrees reasonably well with the measured intracellular $\mathrm{NO}_{3}^{-}$consumption rates of 0.14-0.36 nmol $\mathrm{NO}_{3}^{-}$aggregate ${ }^{-1} \mathrm{~h}^{-1}$. In sharp contrast to axenic $S$. marinoi cultures, however, the consumption of intracellular $\mathrm{NO}_{3}^{-}$by aggregate-associated $S$. marinoi cells was not accompanied by the concurrent release of $\mathrm{NH}_{4}^{+}$, which argues against DNRA by aggregate-associated $S$. marinoi as a major nitrate sink. Instead, the ${ }^{15} \mathrm{~N}$-labeling experiment clearly indicated that much of the $\mathrm{NO}_{3}^{-}$initially stored by $S$. marino $i$ was used for dissimilatory $\mathrm{NO}_{3}^{-}$reduction by the diverse microbial community of the aggregates. This interpretation is supported by the observations that (a) only a small fraction of the intracellular $\mathrm{NO}_{3}^{-}$was converted to ${ }^{\mathrm{IC}} \mathrm{NH}_{4}^{+}$(the pathway that can be carried out by axenic $S$. marinoi), while a much larger fraction was converted to ${ }^{\mathrm{IC}} \mathrm{NO}_{2}^{-}$and ${ }^{\mathrm{IC}} \mathrm{N}_{2}$ (that were not produced by axenic S. marinoi), (b) the aggregates produced ${ }^{\mathrm{IC}} \mathrm{NH}_{4}^{+}$with a delay of 2 days, whereas axenic S. marinoi produced ${ }^{\mathrm{IC}} \mathrm{NH}_{4}^{+}$immediately after the onset of dark and anoxic conditions, and (c) the time course and the products of dissimilatory $\mathrm{NO}_{3}^{-}$reduction inside the aggregates were very similar, irrespective of whether driven by intracellular or extracellular $\mathrm{NO}_{3}^{-}$.

The mechanism of intracellular $\mathrm{NO}_{3}^{-}$transfer from the diatom cells to the microbial community of the aggregates is 
currently unknown. Living diatom cells inside the aggregates may continuously leak $\mathrm{NO}_{3}^{-}$under anoxic conditions, especially if the aggregate porewater is $\mathrm{NO}_{3}^{-}$-depleted and the diatoms are unable to maintain the steep concentration gradient across the plasma membrane. Under dark and anoxic conditions, diatoms are apparently unable to refill their intracellular $\mathrm{NO}_{3}^{-}$stores (see above), which would then lead to a net loss of intracellular $\mathrm{NO}_{3}^{-}$. However, $\mathrm{NO}_{3}^{-}$leakage was never observed in axenic cultures of S. marinoi, nor in T. weissflogii or A. coffeaeformis, since the extracellular $\mathrm{NO}_{3}^{-}$concentration does not increase while the intracellular $\mathrm{NO}_{3}^{-}$is consumed under dark and anoxic conditions (Kamp et al., 2011, 2013). Alternatively, decaying or lysing diatom cells may gradually release intracellular $\mathrm{NO}_{3}^{-}$ into the aggregate if, for instance, cell lysis is triggered by viral infection (Kimura and Tomarua, 2015; Kim et al., 2015). Viral-mediated mortality and cellular lysis could be especially high in the aggregates with high cell densities (Brussaard, 2004). S. marinoi, like many other microalgae, is also known to undergo programmed cell death (PCD) when stressed (Bidle and Falkowski, 2004; Orefice et al., 2015). Anoxia inside the aggregates might act as the stressor triggering PCD in diatoms.

An alternative scenario could be that aggregate-associated S. marinoi only reduce $\mathrm{NO}_{3}^{-}$to $\mathrm{NO}_{2}^{-}$, and the $\mathrm{NO}_{2}^{-}$is then immediately excreted by the cell to be further reduced to $\mathrm{N}_{2}$ and $\mathrm{NH}_{4}^{+}$by the microbial community of the aggregates. S. marinoi is known to survive dark and anoxic conditions for much longer than the 6 and $72 \mathrm{~h}$ covered in the ${ }^{15} \mathrm{~N}$ stable isotope experiments with axenic cultures and diatombacteria aggregates, respectively. Axenic S. marinoi was viable after both the $24-\mathrm{h}$ starvation procedure in this study, and the 9-week incubation under dark and anoxic conditions in a previous study (Kamp et al., 2011). Thus, it cannot be ruled out that the aggregate-associated $S$. marinoi remained viable during the 72-h incubation under dark and anoxic conditions and displayed DNRN activity. It is currently not known, however, why S. marinoi should potentially shift from DNRA to DNRN when associated with sinking aggregates, but the observed increase in ${ }^{\mathrm{IC}} \mathrm{NO}_{2}^{-}$concentration indeed coincides with the decrease in intracellular $\mathrm{NO}_{3}^{-}$concentration. Additionally, this scenario would explain both the similar rates and the gradual nature of intracellular $\mathrm{NO}_{3}^{-}$consumption in free-living vs. aggregate-associated $S$. marinoi (see above). Nitrite excretion is a common phenomenon in marine phytoplankton, including diatoms (Collos, 1998; Mackey et al., 2011) and has also been reported for an axenic strain of T. weissflogii capable of DNRA (Kamp et al., 2013).

\section{Ecological Implications of Intracellular Nitrate in Diatom-Bacteria Aggregates}

Sinking aggregates mediate much of the vertical carbon export to the seafloor and thereby represent an integral component of the "biological pump" in the ocean (Turner, 2015). Our finding that diatom-bacteria aggregates store intracellular $\mathrm{NO}_{3}^{-}$ in high amounts suggests that sinking aggregates may also be involved in the vertical transport of $\mathrm{NO}_{3}^{-}$to deep water layers or even to the seafloor. Nitrate accumulation by diatoms only occurs in the presence of $\mathrm{O}_{2}$ and thus diatombacteria aggregates may take up $\mathrm{NO}_{3}^{-}$in the euphotic zone and oxygenated subsurface layers and export it to the deep ocean.

Depending on the initial amount of $\mathrm{NO}_{3}^{-}$stored in sinking diatom-bacteria aggregates, the intracellular $\mathrm{NO}_{3}^{-}$consumption rate, the internal and ambient $\mathrm{O}_{2}$ concentration, temperature, the water depth, and the sinking velocity of the aggregates, a fraction of the intracellular $\mathrm{NO}_{3}^{-}$stores might reach the seafloor. At the experimental conditions of this study (i.e., $15^{\circ} \mathrm{C}, 0 \mu \mathrm{mol}$ $\mathrm{O}_{2} \mathrm{~L}^{-1}$ ), the half-life of the intracellular $\mathrm{NO}_{3}^{-}$pool of the aggregates was $\sim 24 \mathrm{~h}$. Sinking velocities of diatom-bacteria aggregates of the same size as used in this study are in the range of 50-300 $\mathrm{m} \mathrm{d}^{-1}$ (Iversen and Ploug, 2013). Thus, settling aggregates that still contain half of their initial intracellular $\mathrm{NO}_{3}^{-}$content would be expected to settle on sediments at 50$300 \mathrm{~m}$ water depth where they may sustain benthic denitrification (Lehto et al., 2014). Aggregates exposed to lower temperatures and higher ambient $\mathrm{O}_{2}$ concentrations in situ could transport intracellular $\mathrm{NO}_{3}^{-}$down to considerably greater depths. More experimental work and modeling efforts will be necessary to refine these estimates. Irrespective of its unsettled quantification, the export of intracellular $\mathrm{NO}_{3}^{-}$to deep water layers in the ocean represents a rarely considered mechanism of fixed-nitrogen loss from the euphotic zone (Lehto et al., 2014; Stief et al., 2016). Future in situ studies should also quantify the transport of intracellular $\mathrm{NO}_{3}^{-}$by sinking aggregates in comparison to the successive depletion of their organic fraction in nitrogen relative to carbon (Martin et al., 1987; Smith et al., 1992; Dang and Lovell, 2016).

The intracellular $\mathrm{NO}_{3}^{-}$pool in diatom-bacteria aggregates may allow diatoms to survive anoxic conditions while the aggregates sink through oxygen-depleted water layers (Kamp et al., 2011). Pelagic diatoms are well-known to survive the descent to the seafloor even at great water depth (Fileman et al., 1998) and can indeed be found in viable resting stages in marine sediments (Lewis et al., 1999; Härnström et al., 2011). As shown in this study, the diatom-derived $\mathrm{NO}_{3}^{-}$also drives the metabolic activity of the (facultative) anaerobic bacterial community of the aggregates. The presence of bacteria actively mediating dissimilatory $\mathrm{NO}_{3}^{-}$ reduction has been repeatedly confirmed for marine snow, small particles, and sinking zooplankton carcasses (Tuomainen et al., 2003; Woebken et al., 2007; Ganesh et al., 2014, 2015; Glud et al., 2015). The internal availability of $\mathrm{NO}_{3}^{-}$may not only allow these bacteria to remain active under anoxic conditions, but may also act as a selection factor in the succession of bacterial communities in sinking diatom-bacteria aggregates. Marine snow is mainly colonized by bacteria in the euphotic zone, but the microbial community composition is known to change during the descent (Tang et al., 2010; Thiele et al., 2015), which potentially is influenced by the presence of an internal $\mathrm{NO}_{3}^{-}$source when $\mathrm{O}_{2}$ is absent.

The $\mathrm{NO}_{3}^{-}$initially stored by diatom cells is expected to drive intense anaerobic nitrogen cycling inside partially or completely anoxic diatom-bacteria aggregates sinking to the seafloor. In this study, the rates of $\mathrm{NO}_{2}^{-}, \mathrm{N}_{2}$, and $\mathrm{NH}_{4}^{+}$ production driven by diatom-derived $\mathrm{NO}_{3}^{-}$were $\sim 7$ times lower 
than those fueled by extracellular $\mathrm{NO}_{3}^{-}$. This indicates that inside the aggregate the supply rate of intracellular $\mathrm{NO}_{3}^{-}$for anaerobic nitrogen cycling was lower than that of extracellular $\mathrm{NO}_{3}^{-}$. However, the relative importance of intracellular $\mathrm{NO}_{3}^{-}$is expected to be higher at lower extracellular $\mathrm{NO}_{3}^{-}$concentrations and in larger, diffusion-limited aggregates (Stief et al., 2016). Notably, intracellular $\mathrm{NO}_{3}^{-}$is an internal $\mathrm{NO}_{3}^{-}$source that diatom-bacteria aggregates can exploit even in $\mathrm{NO}_{3}^{-}$-depleted environments.

The finding that the diatom $S$. marinoi is capable of DNRA suggests that diatom-bacteria aggregates represent a pelagic $\mathrm{NH}_{4}^{+}$source in addition to organic matter mineralization (Kalvelage et al., 2013). The potential role of sinking aggregates and suspended particles as an important $\mathrm{NH}_{4}^{+}$source for the anammox process in OMZs has been discussed before (Dalsgaard et al., 2012; Kalvelage et al., 2013; Stief et al., 2016). Aggregateassociated DNRA activity may thereby fuel the anammox activity of free-living or particle-associated bacteria and thus be indirectly involved in fixed-nitrogen loss from the ocean (Stief et al., 2016). The results of this study, however, clearly indicate that at least part of the intracellular $\mathrm{NO}_{3}^{-}$stored by aggregate-associated diatoms drives fixed-nitrogen loss directly inside the aggregates. Intracellular $\mathrm{NO}_{3}^{-}$is transferred from the diatoms to the bacterial community of the aggregates, potentially aided by viral-induced cell lysis (Kim et al., 2015; Kimura and Tomarua, 2015), and then converted to nitrogen gas by denitrification. Toward the end of the 3-day incubation, significant ${ }^{\mathrm{IC}} \mathrm{NH}_{4}^{+}$production was also observed, but since the intracellular $\mathrm{NO}_{3}^{-}$pool was depleted by that time, this $\mathrm{NH}_{4}^{+}$production was most likely mediated by bacteria.

The environmental scenario emerging from this study on intracellular $\mathrm{NO}_{3}^{-}$dynamics in diatom-bacteria aggregates can be crudely split into three consecutive phases (Figure 5):

(a) Under the light and oxic conditions in the euphotic zone, diatoms are able to accumulate $\mathrm{NO}_{3}^{-}$intracellularly, even against a steep concentration gradient. Due to the high ambient $\mathrm{O}_{2}$ levels, the anoxic center of aggregates will be small or even absent and hence the rates of anaerobic nitrogen cycling will be low or zero.

(b) During the descent, aggregates may pass through layers of reduced $\mathrm{O}_{2}$ levels, which will increase the anoxic volume inside the aggregate and sustain anaerobic nitrogen cycling. Living diatoms will perform DNRA, while decaying diatoms will pass on their intracellular $\mathrm{NO}_{3}^{-}$stores to the aggregateassociated bacterial community which performs diverse processes of anaerobic nitrogen cycling.

(c) Upon settlement of the aggregates onto the seafloor, the remaining intracellular $\mathrm{NO}_{3}^{-}$stores (if any) may fuel benthic anaerobic nitrogen cycling, which might be further stimulated by the induction of anoxic conditions in the sediment around the aggregate.

In summary, the nitrate-concentrating capacity of aggregateassociated diatoms has the potential to impact nitrogen cycling, including fixed-nitrogen loss, not only in the photic zone, but also in the mesopelagic and benthic compartments.

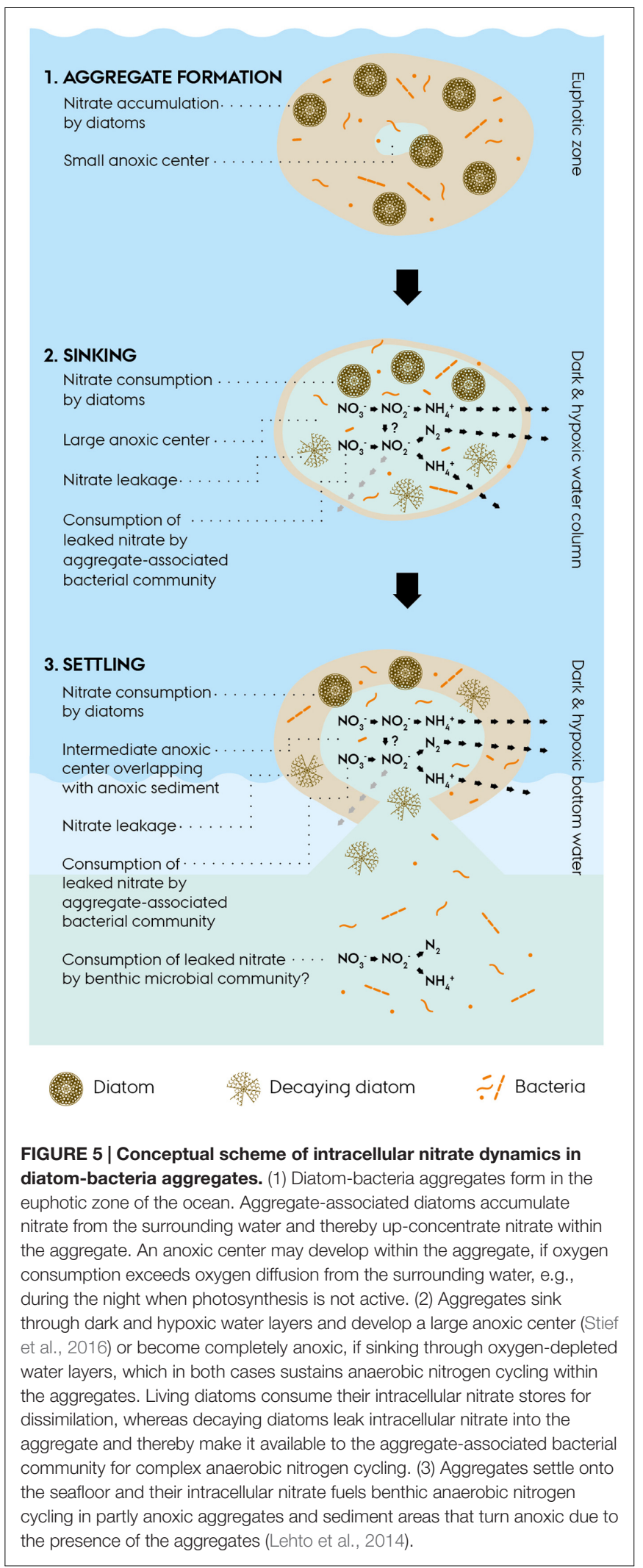




\section{AUTHOR CONTRIBUTIONS}

AK, PS, BT, and RG designed the study. AK and PS carried out the experiments. AK, PS, and LB measured the samples. All authors interpreted the data. AK wrote the manuscript with input from all co-authors.

\section{FUNDING}

Financial support was provided by a grant from the German Research Foundation awarded to AK (KA 3187/2-1), a grant from FNU awarded to RG and BT (0602-02276B), and the HADESERC Advanced Investigator Grant awarded to RG (669947).

\section{REFERENCES}

Armbrust, E. V., Berges, J. A., Bowler, C., Green, B. R., Martinez, D., Putnam, N. H., et al. (2004). The genome of the diatom Thalassiosira pseudonana: ecology, evolution, and metabolism. Science 306, 79-86. doi: 10.1126/science.1101156

Bender, S. J., Parker, M. S., and Armbrust, E. V. (2012). Coupled effects of light and nitrogen source on the urea cycle and nitrogen metabolism over a diel cycle in the marine diatom Thalassiosira pseudonana. Protist 163, 232-251. doi: 10.1016/j.protis.2011.07.008

Bernhard, J. M., Casciotti, K. L., McIlvin, M. R., Beaudoin, D. J., Visscher, P. T., and Edgcomb, V. P. (2012). Potential importance of physiologically diverse benthic foraminifera in sedimentary nitrate storage and respiration. J. Geophys. Res. 117:G03002. doi: 10.1029/2012JG001949

Bidle, K. D., and Falkowski, P. G. (2004). Cell death in planktonic, photosynthetic microorganisms. Nat. Rev. Microbiol. 2, 643-655. doi: 10.1038/nrmicro956

Boetius, A., Albrecht, S., Bakker, K., Bienhold, C., Felden, J., FernándezMéndez, M., et al. (2013). Export of algal biomass from the melting Arctic sea ice. Science 339, 1430-1432. doi: 10.1126/science.1231346

Boetius, A., Anesio, A. M., Deming, J. W., Mikucki, J. A., and Rapp, J. Z. (2015). Microbial ecology of the cryosphere: sea ice and glacial habitats. Nat. Rev. Microbiol. 13, 677-690. doi: 10.1038/nrmicro3522

Bowler, C., Allen, A. E., Badger, J. H., Grimwood, J., Jabbari, K., Kuo, A., et al. (2008). The Phaeodactylum genome reveals the evolutionary history of diatom genomes. Nature 456, 239-244. doi: 10.1038/nature07410

Bresnan, E., Hay, S., Hughes, S. L., Fraser, S., Rasmussen, J., Webster, L., et al. (2009). Seasonal and interannual variation in the phytoplankton community in the north east of Scotland. J. Sea Res. 61, 17-25. doi: 10.1016/j.seares.2008.05.007

Brown, K. L., Twing, K. I., and Robertson, D. L. (2009). Unraveling the regulation of nitrogen assimilation in the marine diatom Thalassiosira pseudonana (Bacillariophyceae): diurnal variations in transcript levels for five genes involved in nitrogen assimilation. J. Phycol. 45, 413-426. doi: 10.1111/j.15298817.2009.00648.x

Brussaard, C. P. D. (2004). Viral control of phytoplankton populations - a review. J. Eukaryot. Microbiol. 51, 125-138. doi: 10.1111/j.1550-7408.2004.tb00537.x

Clark, D. R., Flynn, K. J., and Owens, N. J. P. (2002). The large capacity for dark nitrate-assimilation in diatoms may overcome nitrate limitation of growth. New Phytol. 155, 101-108. doi: 10.1046/j.1469-8137.2002.00435.x

Collos, Y. (1998). Nitrate uptake, nitrite release and uptake, and new production estimates. Mar. Ecol. Prog. Ser. 171, 293-301. doi: 10.3354/meps171293

Collos, Y., Siddiqi, M. Y., Wang, M. Y., Glass, A. D. M., and Harrison, P. J. (1992). Nitrate uptake kinetics by two marine diatoms using the radioactive tracer $13 \mathrm{~N}$. J. Exp. Mar. Biol. Ecol. 163, 251-260. doi: 10.1016/0022-0981(92)90053-D

Dalsgaard, T., Thamdrup, B., Farias, L., and Revsbech, N. P. (2012). Anammox and denitrification in the oxygen minimum zone of the eastern South Pacific. Limnol. Oceanogr. 57, 1331-1346. doi: 10.4319/lo.2012.57.5.1331

Dang, H. Y., and Lovell, C. R. (2016). Microbial surface colonization and biofilm development in marine environments. Microbiol. Mol. Biol. Rev. 80, 91-138. doi: 10.1128/MMBR.00037-15

\section{ACKNOWLEDGMENTS}

We thank Dina Holmgård Skov for help with nitrate measurements and Anni Glud for technical support. Ugo Marzocchi is acknowledged for helpful discussions and critical input on the conceptual scheme (Figure 5), and Ann Sofie B. Lundgaard for practical assistance.

\section{SUPPLEMENTARY MATERIAL}

The Supplementary Material for this article can be found online at: http://journal.frontiersin.org/article/10.3389/fmicb. 2016.01669/full\#supplementary-material

Degerlund, M., and Eilertsen, H. C. (2010). Main species characteristics of phytoplankton spring blooms in NE atlantic and arctic waters (68-80A degrees N). Estuaries Coast 33, 242-269. doi: 10.1007/s12237-009-9167-7

Eppley, R. W., and Coatsworth, J. L. (1968). Uptake of nitrate and nitrite by Ditylum brightwellii - kinetics and mechanisms. J. Phycol. 4, 151-156. doi: 10.1111/j.1529-8817.1968.tb04689.x

Eppley, R. W., and Rogers, J. N. (1970). Inorganic nitrogen assimilation of Ditylum brightwellii, a marine plankton diatom. J. Phycol. 6, 344-351. doi: 10.1111/j.0022-3646.1970.00344.x

Fernández-Méndez, M., Wenzhoefer, F., Peeken, I., Sorensen, H. L., Glud, R. N., and Boetius, A. (2014). Composition, buoyancy regulation and fate of ice algal aggregates in the central Arctic Ocean. PLOS ONE 9:e107452. doi: 10.1371/journal.pone.0107452

Fileman, T. W., Pond, D. W., Barlow, R. G., and Mantoura, R. F. C. (1998). Vertical profiles of pigments, fatty acids and amino acids: evidence for undegraded diatomaceous material sedimenting to the deep ocean in the Bellingshausen Sea, Antarctica. Deep Sea Res. Part I Oceanogr. Res. Pap. 45, 333-346. doi: 10.1016/S0967-0637(97)00824-8

Füssel, J., Lam, P., Lavik, G., Jensen, M. M., Holtappels, M., Günter, M., et al. (2012). Nitrite oxidation in the Namibian oxygen minimum zone. ISME J. 6, 1200-1209. doi: 10.1038/ismej.2011.178

Ganesh, S., Bristow, L. A., Larsen, M., Sarode, N., Thamdrup, B., and Stewart, F. J. (2015). Size-fraction partitioning of community gene transcription and nitrogen metabolism in a marine oxygen minimum zone. ISME J. 9, 2682-2696. doi: 10.1038/ismej.2015.44

Ganesh, S., Parris, D. J., De Long, E. F., and Stewart, F. J. (2014). Metagenomic analysis of size-fractionated picoplankton in a marine oxygen minimum zone. ISME J. 8, 187-211. doi: 10.1038/ismej.2013.144

Glibert, P. M., Wilkerson, F. P., Dugdale, R. C., Raven, J. A., Dupont, C. L., Leavitt, P. R., et al. (2016). Pluses and minuses of ammonium and nitrate uptake and assimilation by phytoplankton and implications for productivity and community composition, with emphasis on nitrogen-enriched conditions. Limnol. Oceanogr. 61, 165-197. doi: 10.1002/lno.10203

Glud, R. N., Grossart, H.-P., Larsen, M., Tang, K. W., Arendt, K. E., Rysgaard, S., et al. (2015). Copepod carcasses as microbial hot spots for pelagic denitrification. Limnol. Oceanogr. 60, 2026-2036. doi: 10.1002/lno. 10149

Glud, R. N., Rysgaard, S., Turner, G., McGinnis, D. F., and Leakey, R. J. G. (2014). Biological- and physical-induced oxygen dynamics in melting sea ice of the Fram Strait. Limnol. Oceanogr. 59, 1097-1111. doi: 10.4319/lo.2014.59.4.1097

Glud, R. N., Thamdrup, B., Stahl, H., Wenzhoefer, F., Glud, A., Nomaki, H., et al. (2009). Nitrogen cycling in a deep ocean margin sediment (Sagami Bay, Japan). Limnol. Oceanogr. 54, 723-734. doi: 10.4319/lo.2009.54.3.0723

Grossart, H. P., Berman, T., Simon, M., and Pohlmann, K. (1998). Occurrence and microbial dynamics of macroscopic organic aggregates (lake snow) in Lake Kinneret, Israel, in fall. Aquat. Microb. Ecol. 14, 59-67. doi: 10.3354/ame014059

Guillard, R. R. L., and Ryther, J. H. (1962). Studies of marine planktonic diatoms. I. Cyclotella nana Hustedt and Detonula confervacea Cleve. Can. J. Microbiol. 8, 229-239. 
Härnström, K., Ellegaard, M., Andersen, T. J., and Godhe, A. (2011). Hundred years of genetic structure in a sediment revived diatom population. Proc. Natl. Acad. Sci. U.S.A. 108, 4252-4257. doi: 10.1073/pnas.1013528108

Heisterkamp, I. M., Kamp, A., Schramm, A. T., de Beer, D., and Stief, P. (2012). Indirect control of the intracellular nitrate pool of intertidal sediment by the polychaete Hediste diversicolor. Mar. Ecol. Prog. Ser. 445, 181-192. doi: 10.3354/meps09464

Høgslund, S., Revsbech, N. P., Cedhagen, T., Nielsen, L. P., and Gallardo, V. A. (2008). Denitrification, nitrate turnover, and aerobic respiration by benthic foraminiferans in the oxygen minimum zone off Chile. J. Exp. Mar. Biol. Ecol. 359, 85-91. doi: 10.1016/j.jembe.2008.02.015

Iversen, M. H., and Ploug, H. (2013). Temperature effects on carbon-specific respiration rate and sinking velocity of diatom aggregates - potential implications for deep ocean export processes. Biogeosciences 10, 4073-4085. doi: 10.5194/bg-10-4073-2013

Jewson, D. H., Lowry, S. F., and Bowen, R. (2006). Co-existence and survival of diatoms on sand grains. Eur. J. Phycol. 41, 131-146. doi: $10.1080 / 09670260600652903$

Kalvelage, T., Lavik, G., Lam, P., Contreras, S., Arteaga, L., Loescher, C. R., et al. (2013). Nitrogen cycling driven by organic matter export in the South Pacific oxygen minimum zone. Nat. Geosci. 6, 228-234. doi: 10.1038/ngeo1739

Kamp, A., de Beer, D., Nitsch, J. L., Lavik, G., and Stief, P. (2011). Diatoms respire nitrate to survive dark and anoxic conditions. Proc. Natl. Acad. Sci. U.S.A. 108, 5649-5654. doi: 10.1073/pnas.1015744108

Kamp, A., Høgslund, S., Risgaard-Petersen, N., and Stief, P. (2015). Nitrate storage and dissimilatory nitrate reduction by eukaryotic microbes. Front. Microbiol. 6:1492. doi: 10.3389/fmicb.2015.01492

Kamp, A., Stief, P., Knappe, J., and de Beer, D. (2013). Response of the ubiquitous pelagic diatom Thalassiosira weissflogii to darkness and anoxia. PLoS ONE 8:e82605. doi: 10.1371/journal.pone.0082605

Kim, J., Yoon, S.-H., and Choi, T.-J. (2015). Isolation and physiological characterization of a novel virus infecting Stephanopyxis palmeriana (Bacillariophyta). Algae 30, 81-87. doi: 10.4490/algae.2015.30.2.081

Kimura, K., and Tomarua, Y. (2015). Discovery of two novel viruses expands the diversity of single-stranded DNA and single-stranded RNA viruses infecting a cosmopolitan marine diatom. Appl. Environ. Microbiol. 81, 1120-1131. doi: 10.1128/AEM.02380-14

Klawonn, I., Bonaglia, S., Bruchert, V., and Ploug, H. (2015). Aerobic and anaerobic nitrogen transformation processes in N2-fixing cyanobacterial aggregates. ISME J. 9, 1456-1466. doi: 10.1038/ismej.2014.232

Kraft, B., Strous, M., and Tegetmeyer, H. E. (2011). Microbial nitrate respiration Genes, enzymes and environmental distribution. J. Biotechnol. 155, 104-117. doi: 10.1016/j.jbiotec.2010.12.025

Leblanc, K., Arístegui, J., Armand, L., Assmy, P., Beker, B., Bode, A., et al. (2012). A global diatom database - abundance, biovolume and biomass in the world ocean. Earth Syst. Sci. Data 4, 149-165. doi: 10.5194/essd-4-149-2012

Lehto, N., Glud, R. N., Nordi, G. A., Zhang, H., and Davison, W. (2014). Anoxic microniches in marine sediments induced by aggregate settlement: biogeochemical dynamics and implications. Biogeochemistry 119, 307-327.

Lewis, J., Harris, A. S. D., Jones, K. J., and Edmonds, R. L. (1999). Long-term survival of marine planktonic diatoms and dinoflagellates in stored sediment samples. J. Plankton Res. 21, 343-354. doi: 10.1093/plankt/21.2.343

Lomas, M. W., and Glibert, P. M. (1999a). Temperature regulation of nitrate uptake: a novel hypothesis about nitrate uptake and reduction in cool-water diatoms. Limnol. Oceanogr. 44, 556-572. doi: 10.4319/lo.1999.44.3.0556

Lomas, M. W., and Glibert, P. M. (1999b). Interactions between NH4+ and NO3uptake and assimilation: comparison of diatoms and dinoflagellates at several growth temperatures. Mar. Biol. 133, 541-551. doi: 10.1007/s002270050494

Mackey, K. R. M., Bristow, L., Parks, D. R., Altabet, M. A., Post, A. F., and Paytan, A. (2011). The influence of light on nitrogen cycling and the primary nitrite maximum in a seasonally stratified sea. Prog. Oceanogr. 91, 545-560. doi: 10.1016/j.pocean.2011.09.001

Martin, J. H., Knauer, G. A., Karl, D. M., and Broenkow, W. W. (1987). VERTEX: carbon cycling in the northeast Pacific. Deep Sea Res. II 34, 267-285. doi: 10.1016/0198-0149(87)90086-0

McIlvin, M. R., and Altabet, M. A. (2005). Chemical conversion of nitrate and nitrite to nitrous oxide for nitrogen and oxygen isotopic analysis in freshwater and seawater. Anal. Chem. 77, 5589-5595. doi: 10.1021/ac050528s
McQuoid, M. R., Godhe, A., and Nordberg, K. (2002). Viability of phytoplankton resting stages in the sediments of a coastal Swedish fjord. Eur. J. Phycol. 37, 191-201. doi: 10.1017/S0967026202003670

Nielsen, L. P. (1992). Denitrification in sediment determined from nitrogen isotope pairing. FEMS Microbiol. Ecol. 86, 357-362. doi: 10.1016/j.chemosphere.2013.07.063

Orefice, I., Lauritano, C., Procaccini, G., Ianora, A., and Romano, G. (2015). Insights into possible cell-death markers in the diatom Skeletonema marinoi in response to senescence and silica starvation. Mar. Genomics 24, 81-88. doi: 10.1016/j.margen.2015.06.008

Piña-Ochoa, E., Høgslund, S., Geslin, E., Cedhagen, T., Revsbech, N. P., Nielsen, L. P., et al. (2010a). Widespread occurrence of nitrate storage and denitrification among Foraminifera and Gromiida. Proc. Natl. Acad. Sci. U.S.A. 107, 11481153. doi: 10.1073/pnas.0908440107

Piña-Ochoa, E., Koho, K. A., Geslin, E., and Risgaard-Petersen, N. (2010b). Survival and life strategy of the foraminiferan Globobulimina turgida through nitrate storage and denitrification. Mar. Ecol. Prog. Ser. 417, 39-49. doi: $10.3354 /$ meps08805

Ploug, H., and Bergkvist, J. (2015). Oxygen diffusion limitation and ammonium production within sinking diatom aggregates under hypoxic and anoxic conditions. Mar. Chem. 176, 142-149. doi: 10.1016/j.marchem.2015.08.012

Ploug, H., Kühl, M., Buchholz-Cleven, B., and Jørgensen, B. B. (1997). Anoxic aggregates - an ephemeral phenomenon in the pelagic environment? Aquat. Microb. Ecol. 13, 285-294. doi: 10.3354/ame013285

Prihoda, J., Tanaka, A., de Paula, W. B. M., Allen, J. F., Tirichine, L., and Bowler, C. (2012). Chloroplast-mitochondria cross-talk in diatoms. J. Exp. Bot. 63, 15431557. doi: 10.1093/jxb/err441

Riley, G. A. (1963). Organic aggregates in seawater and the dynamics of their formation and utilization. Limnol. Oceanogr. 8, 372-381. doi: 10.4319/lo.1963.8.4.0372

Risgaard-Petersen, N., Langezaal, A. M., Ingvardsen, S., Schmid, M. C., Jetten, M. S. M., Op den Camp, H. J. M., et al. (2006). Evidence for complete denitrification in a benthic foraminifer. Nature 443, 93-96. doi: 10.1038/nature05070

Shanks, A. L., and Trent, J. D. (1979). Marine snow: microscale nutrient patches. Limnol. Oceanogr. 24, 850-854. doi: 10.4319/lo.1979.24. 5.0850

Silver, M. W., Shanks, A. L., and Trent, J. D. (1978). Marine snow: microplankton habitat and source of small-scale patchiness in pelagic populations. Science 201, 371-373. doi: 10.1126/science.201.4353.371

Simon, H., Lipsewers, Y. A., Giebel, H.-A., Wiltshire, K. H., and Simon, M. (2014). Temperature effects on aggregation during a spring diatom bloom. Limnol. Oceanogr. 59, 2089-2100. doi: 10.4319/lo.2014.59.6.2089

Simon, M., Grossart, H. P., Schweitzer, B., and Ploug, H. (2002). Microbial ecology of organic aggregates in aquatic ecosystems. Aquat. Microb. Ecol. 28, 175-211. doi: 10.3354/ame028175

Smetacek, V. S. (1985). Role of sinking in diatom life-history cycles: ecological, evolutionary and geological significance. Mar. Biol. 84, 239-251. doi: 10.1007/BF00392493

Smith, D. C., Simon, M., Alldredge, A. L., and Azam, F. (1992). Intense hydrolytic enzyme activity on marine aggregates and implications for rapid particle dissolution. Nature 359, 139-142. doi: 10.1038/359 $139 \mathrm{a} 0$

Stief, P., Fuchs-Ocklenburg, S., Kamp, A., Manohar, C. S., Houbraken, J., Boekhout, T., et al. (2014). Dissimilatory nitrate reduction by Aspergillus terreus isolated from the seasonal oxygen minimum zone in the Arabian Sea. $B M C$ Microbiol. 14:35. doi: 10.1186/1471-2180-14-35

Stief, P., Kamp, A., Thamdrup, B., and Glud, R. N. (2016). Anaerobic nitrogen turnover by sinking diatom aggregates at varying ambient oxygen levels. Front. Microbiol. 7:98. doi: 10.3389/fmicb.2016.00098

Tang, X., Gao, G., Chao, J., Wang, X., Zhu, G., and Qin, B. (2010). Dynamics of organic-aggregate-associated bacterial communities and related environmental factors in Lake Taihu, a large eutrophic shallow lake in China. Limnol. Oceanogr. 55, 469-480. doi: 10.4319/lo.2009.55.2.0469

Tantanasarit, C., Englande, A., and Babel, S. (2013). Nitrogen, phosphorus and silicon uptake kinetics by marine diatom Chaetoceros calcitrans under high nutrient concentrations. J. Exp. Mar. Biol. Ecol. 446, 67-75. doi: 10.1016/j.jembe.2013.05.004 
Thamdrup, B. (2012). New pathways and processes in the global nitrogen cycle. Annu. Rev. Ecol. Evol. Syst. 43, 407-428. doi: 10.1146/annurev-ecolsys-102710145048

Thiele, S., Fuchs, B. M., Amann, R., and Iversen, M. H. (2015). Colonization in the photic zone and subsequent changes during sinking determine bacterial community composition in marine snow. Appl. Environ. Microbiol. 81, 14631471. doi: 10.1128/AEM.02570-14

Thornton, D. C. O. (2002). Diatom aggregation in the sea: mechanisms and ecological implications. Eur. J. Phycol. 37, 149-161. doi: $10.1017 /$ S0967026202003657

Tuomainen, J. M., Hietanen, S., Kuparinen, J., Martikainen, P. J., and Servomaa, K. (2003). Baltic Sea cyanobacterial bloom contains denitrification and nitrification genes, but has negligible denitrification activity. FEMS Microbiol. Ecol. 45, 83-96. doi: 10.1016/S0168-6496(03) 00131-4

Turner, J. T. (2015). Zooplankton fecal pellets, marine snow, phytodetritus and the ocean's biological pump. Prog. Oceanogr. 130, 205-248. doi: 10.1016/j.pocean.2014.08.005
Woebken, D., Fuchs, B. M., Kuypers, M. M. M., and Amann, R. (2007) Potential interactions of particle-associated anammox bacteria with bacterial and archaeal partners in the Namibian upwelling system. Appl. Environ. Microbiol. 73, 4648-4657. doi: 10.1128/AEM.02774-06

Zhou, Z. M., Takaya, N., Nakamura, A., Yamaguchi, M., Takeo, K., and Shoun, H. (2002). Ammonia fermentation, a novel anoxic metabolism of nitrate by fungi. J. Biol. Chem. 277, 1892-1896. doi: 10.1074/jbc.M109096200

Conflict of Interest Statement: The authors declare that the research was conducted in the absence of any commercial or financial relationships that could be construed as a potential conflict of interest.

Copyright ( 2016 Kamp, Stief, Bristow, Thamdrup and Glud. This is an open-access article distributed under the terms of the Creative Commons Attribution License (CC BY). The use, distribution or reproduction in other forums is permitted, provided the original author(s) or licensor are credited and that the original publication in this journal is cited, in accordance with accepted academic practice. No use, distribution or reproduction is permitted which does not comply with these terms. 